\title{
Increased levels of Stress-inducible phosphoprotein-1 accelerates amyloid- $\beta$ deposition in a mouse model of Alzheimer's disease
}

Rachel E. Lackie ${ }^{1,2 \dagger}$, Jose Marques-Lopes ${ }^{1 \dagger}$, Valeriy G. Ostapchenko ${ }^{1}$, Sarah Good ${ }^{3}$, Wing-Yiu Choy ${ }^{4}$, Patricija van Oosten-Hawle ${ }^{3}$, Stephen H. Pasternak ${ }^{1,5,6}$, Vania F. Prado ${ }^{1,2,7,8^{*}+}$ and Marco A. M. Prado ${ }^{1,2,7,8^{*}+}$ (D)

\begin{abstract}
Molecular chaperones and co-chaperones, which are part of the protein quality control machinery, have been shown to regulate distinct aspects of Alzheimer's Disease (AD) pathology in multiple ways. Notably, the co-chaperone STI1, which presents increased levels in AD, can protect mammalian neurons from amyloid- $\beta$ toxicity in vitro and reduced STI1 levels worsen A $\beta$ toxicity in C. elegans. However, whether increased STI1 levels can protect neurons in vivo remains unknown. We determined that overexpression of STI1 and/or Hsp90 protected C. elegans expressing A $\beta_{(3-42)}$ against A $\beta$-mediated paralysis. Mammalian neurons were also protected by elevated levels of endogenous STI1 in vitro, and this effect was mainly due to extracellular STI1. Surprisingly, in the 5xFAD mouse model of AD, by overexpressing STI1, we find increased amyloid burden, which amplifies neurotoxicity and worsens spatial memory deficits in these mutants. Increased levels of STI1 disturbed the expression of Aß-regulating enzymes (BACE1 and MMP-2), suggesting potential mechanisms by which amyloid burden is increased in mice. Notably, we observed that STI1 accumulates in dense-core AD plaques in both 5XFAD mice and human brain tissue. Our findings suggest that elevated levels of STI1 contribute to $A \beta$ accumulation, and that STI1 is deposited in AD plaques in mice and humans. We conclude that despite the protective effects of STI1 in C. elegans and in mammalian cultured neurons, in vivo, the predominant effect of elevated STI1 is deleterious in AD.
\end{abstract}

Keywords: Amyloidosis, Alzheimer's disease, STIP1/HOP, Hsp70, Hsp90, Prion protein

\section{Introduction}

Alzheimer's disease (AD), the most common cause of dementia, afflicts close to 50 million people worldwide and the number of affected individuals is projected to grow by twofold every two decades [1]. Genetic mutations that cause AD favour the abnormal processing of the amyloid

\footnotetext{
* Correspondence: vprado@robarts.ca; mprado@robarts.ca

${ }^{\dagger}$ Rachel E. Lackie, Jose Marques-Lopes, Vania F. Prado and Marco A. M. Prado contributed equally to this work.

${ }^{1}$ Robarts Research Institute, The University of Western Ontario, 1151

Richmond St. N., London, Ontario N6A 5B7, Canada

Full list of author information is available at the end of the article
}

precursor protein (APP), from which the aggregation prone amyloid- $\beta(A \beta)$ peptide is derived [2-5]. In sporadic and familial $A D, A \beta$ peptides accumulate in soluble and diffuse oligomeric forms and are deposited in insoluble extracellular plaques. Over the past two decades it is becoming increasingly apparent that soluble oligomeric forms of $A \beta$ are a major toxin driving other pathologies and inflammation in AD [6-14], supporting the "amyloid hypothesis" $[15,16]$. These small A $\beta$ peptides attack neurons causing neuronal dysfunction many years prior to the appearance of cognitive symptoms, by interacting with distinct neuronal proteins and receptors. 
One of the key receptors involved in $A \beta$ toxicity is the prion protein $\left(\operatorname{PrP}^{\mathrm{C}}\right)$, which interacts with $\mathrm{A} \beta$ oligomers $(\mathrm{A} \beta \mathrm{Os})$ with high-affinity, and this interaction triggers metabotropic glutamate receptor 5 (mGluR5) maladaptive signalling in neurons $[17-20]$. $\operatorname{PrP}^{\mathrm{C}}$ functions as an extracellular scaffolding protein that interacts with multiple ligands and receptors [21-23]. Specifically, Stress-inducible phosphoprotein 1 (STI1, STIP1, or mammalian homolog: Hsp organizing protein, HOP), a Hsp70/Hsp90 cochaperone, once secreted binds to $\operatorname{PrP}^{\mathrm{C}}$, and protects mouse neurons against a number of insults [24-28]. In vitro, extracellular STI1 prevents toxic effects of A $\beta O s$, including neuronal death and decreased long-term potentiation, likely by interfering with $\mathrm{A} \beta \mathrm{O}-\mathrm{PrP}^{\mathrm{C}}$ interaction due to contiguous binding sites for STI1 and $\mathrm{A} \beta \mathrm{O}$ s along $\mathrm{PrP}^{\mathrm{C}}$ [29]. Conversely, functional studies using a C. elegans model of $A \beta$ indicate that knockdown of Hsp90, STI1 and several other co-chaperones increases $A \beta$ toxicity [30]. Notably, STI1 has been identified in a genome-wide transcriptome analysis as one of the top genes regulating ER transcriptome stress response in the brains of sporadic AD patients [31], and STI1 protein levels are upregulated in $\mathrm{AD}$ patient brains [29].

In addition to interacting with $\operatorname{PrP}^{\mathrm{C}}$, STI1 has a conserved role as a co-chaperone for Hsp90 and Hsp70, and disruption of STI1 function significantly interferes with Hsp70/Hsp90 client expression and activity [25, 32-34]. STI1 overexpression rescued mutant huntingtin proteotoxicity in yeast by reorganizing cytotoxic huntingtin into large high-molecular weight foci [35], suggesting that increased STI1 levels could regulate amyloid aggregation and lessen amyloid toxicity in mice by multiple mechanisms. Molecular chaperones such as Hsp70 and Hsp90 also play critical roles in AD and other protein misfolding diseases [36-39]. In neurodegenerative diseases, there is considerable evidence that molecular chaperone complexes are altered [40] and Hsp90 inhibition in vivo reduced neuronal and synaptic loss due to amyloid toxicity in mice [41]. Moreover, blocking abnormal chaperome interactions have also been shown to improve tau toxicity [40].

Given that STI1 seems to prevent multiple proteotoxic effects in yeast $[35,42,43])$, C. elegans $[30,44]$ and mammalian neurons [26, 28, 29, 45], we hypothesized that increased STI1 levels can mitigate A $\beta$ toxicity and aggregation in vivo. We tested this assumption by modulating levels of STI1 in a C. elegans model of A $\beta$ toxicity, in cultured mouse neurons, and by overexpressing STI1 (3-fold) in the 5xFAD mouse model of AD. In C. elegans, STI1 and Hsp90 protected worms against $A \beta$-induced paralysis. We also determined protection of cultured mammalian neurons against $\mathrm{A} \beta \mathrm{O}$ s by endogenous extracellular STI1. In contrast, raising STI1 levels in mice amplified the formation of extracellular $A \beta$ plaques, which increased neurodegeneration. Surprisingly, we found STI1 can accumulate in extracellular plaques in mice and it was also found in mature plaques in humans. Our results suggest a complex relationship between STI1 and amyloid toxicity and indicate that some of the protective effects observed in C. elegans may not directly translate to mammalian systems in vivo, due to the more complex mechanisms of amyloidosis in the latter.

\section{Materials and methods}

Ethics statement

Animals were housed at The University of Western Ontario vivarium and were managed and treated according to the Canadian Council of Animal Care (CCAC) guidelines and Animal Use Protocols (2016-103, 2016-104). Human tissue from autopsy of AD patients was obtained with informed consent and approval from Office of Research Ethics, Protocol 162656E at the University of Western Ontario. Patients were assigned a neuropathological diagnosis by a licenced Neuropathologist certified by the Royal College of Physicians and Surgeons of Canada.

\section{Nematode strains and growth conditions}

C. elegans were grown on Nematode Growth Medium (NGM) plates seeded with the E. coli OP50-1 strain and cultured by standard methods [46]. The C. elegans strain expressing $A \beta_{(3-42)}$ in the body wall muscle (CL2006 (dvIs2 [pcL12(unc-54/human A $\beta$ peptide minigene) + pRF4]) was obtained from the Caenorhabditis Genetics Center. Strains overexpressing HSP-90 in the body wall muscle (AM988 (rmIs347(unc-54p::HSP-90::RFP] [47] and the strain overexpressing STI-1 in the muscle (PPI1972 (unc-54p::STI-1::GFP); a kind gift of Dr. Anat Ben-Zvi, Ben Gurion University, Israel) were crossed into the genetic background of CL2006, resulting in strains PVH50 (AM988 (rmIs347(unc-54p::HSP-90::RFP]; $d v I s 2$ ), and PVH40 (PPI1972 (unc-54p::STI-1::GFP); $d v I s 2$ ), respectively. Overexpression of HSP-90 and STI1 together in the $A \beta_{(3-42)}$ expressing strain was achieved by crossing strain AM988 into the genetic background of PVH40, resulting in strain PVH71 (rmIs347(unc-54p:: HSP-90::RFP);(unc-54p::STI-1::GFP);dvIs2).

\section{Paralysis assays}

An age-synchronised population of 100 animals per strain was scored by monitoring movement via the touch-nose response, using a platinum wire. Animals were transferred to fresh OP50-1 plates or indicated RNAi plates every day. For paralysis assays on RNAi plates, age-synchronised C. elegans were transferred onto hsp-90 RNAi plates at L4 stage to avoid any developmental effects, and onto sti-1 RNAi plates at L1 stage. 


\section{Primary hippocampal neuronal cultures}

Neuronal cultures from E17.5 WT control and TgA pups were generated as described previously [29, 48]. Briefly, hippocampi were separated from dissected brains clear of meninges, and the cells were dissociated using $0.25 \%$ trypsin-EDTA solution (ThermoFisher, Cat\#25200056). Approximately 4-6 $\times 10^{4}$ cells were added to each well in 4-well plates (ThermoFisher, Cat\#176740) pre-coated with Poly-L-Lysine (Catalog\# P6407, Sigma). Cells were plated in Plating medium containing $10 \%$ heat inactivated fetal bovine serum (Catalog\# 12484-028, Gibco), 4.5\% glucose (Catalog\# A2494001, Invitrogen), 1\% Sodium Pyruvate (Catalog\# 11360070, Invitrogen), 1\% Pen/Strep (Catalog\# 11360070, Invitrogen) and 1\% GlutaMAX (Catalog\# 35050-161, Invitrogen) in MEM with Earle's BSS (Catalog \# 11095, Invitrogen). After $4 \mathrm{~h}$ at $37^{\circ} \mathrm{C}$ and $5 \% \mathrm{CO}_{2}$, plating media was removed and replaced with complete Maintenance Medium (Neurobasal Medium, 1\% Pen/Strep, 1\% GlutaMAX and 1\% B27 supplement (Catalog\# 17504044, Gibco). Half of media were replaced with fresh medium every 2 days and experiments were performed after 10-12 days in culture.

\section{Cellular viability assays}

$\mathrm{A} \beta \mathrm{O}$ toxicity was assessed in hippocampal neuronal cultures as described previously [17, 29, 48]. Briefly, neurons were plated in 4-well dishes coated with Poly-LLysine at a seeding density of $1 \times 10^{5}$. A $\beta$ Os were added to 10-12 day old cultures to the final concentration of $1 \mu \mathrm{M}$. After that cultures were incubated for $24-48 \mathrm{~h}$ at $37 \mathrm{C}, 5 \% \mathrm{CO}_{2}$, and the neuronal health was assessed by various methods.

Lactate Dehydrogenase release was assessed in control and TgA hippocampal neurons as described previously [29] using Lactate Dehydrogenase (LDH) Activity Assay Kit (Catalog \# MAK066, Sigma). Briefly, neuronal cultures were grown in a phenol red-free medium for 10 days, treated with $\mathrm{A} \beta \mathrm{O}$ s for $24 \mathrm{~h}$, after which the culture media were collected and cleared by centrifuging for 20 min at $1000 \mathrm{xg}$ and $4{ }^{\circ} \mathrm{C}$. LDH activity was quantified by measuring absorbance at $450 \mathrm{~nm}$ using BioRad iMark Plate Reader.

LIVE/DEAD Viability/Cytotoxicity assay was performed according to the manufacturer's instructions (Cat\#L3224, ThermoFisher). Briefly, 10-11 day old neuronal cultures were treated with $\mathrm{A} \beta \mathrm{O}$ s with or without anti-STI1 antibody (1:500, Bethyl Laboratories, [25]) for $48 \mathrm{~h}$, after which the cells were washed with PBS and incubated for $30 \mathrm{~min}$ in the dark with Calcein-AM and Ethidium homodimer-1. Cultures were then immediately imaged using $488 \mathrm{~nm}$ laser for excitation and 505/20 emmission filter for Calcein and 560/50 emmission filter for Ethidium homodimer-1 using an LSM 510 Confocor 2 confocal microscope equipped with $10 \mathrm{x} / 0.3$ objective.

\section{Mouse line generation and husbandry}

STI1 overexpressing mice, TgA, were generated on a C57BL6/J background as described previously [25, 49]. The 5xFAD Alzheimer's disease mouse line (B6.Cg Tg [APPSwFlLon,PSEN1*M146L"L286V] 6799Vas/J RRID: MGI:034840-JAX) was obtained from The Jackson Laboratory. Mice were crossed to generate TgA-5xFAD and 5xFAD littermate progeny and maintained on a mixed background of B6SJLF1/J and C57BL6/J, with no further backcrossing. Male mice were used for behavioural and immunohistochemical experiments because previous characterization of TgA mice that was necessary for this work was mainly done in male mice. Mice used in experiments were given ad libitum access to food (Harlan) and water. Mice were housed in standard plexiglass cages with 2-4 littermates. Room temperature and humidity were controlled at $22-25^{\circ} \mathrm{C}$ and with 40 $60 \%$ respectively, and the light schedule followed a light/ dark cycle from 7 am-7 pm.

\section{Preparation and purification of $A \beta$ peptides}

$\mathrm{A} \beta_{1-42}$ (rPeptide, Catalog\# 1002) were prepared as monomer films as described previously [29] and stored desiccated at $-80{ }^{\circ} \mathrm{C}$ until use, for up to 2 months. Oligomers were generated and characterized from $A \beta_{1-42}$ films as described previously [29]. Briefly, peptide films were thoroughly dissolved in DMSO to make a $1 \mathrm{mM}$ stock, after which the solution was diluted 10-fold in Ham's F12 Medium (Wisent), centrifuged for $10 \mathrm{~min}$ at $16,100 \times \mathrm{g}$ and then incubated for $24 \mathrm{~h}$ at $4{ }^{\circ} \mathrm{C}$. Preparation quality was regularly checked by SDS-PAGE, probing with the anti-A $\beta$ (6E10, BioLegend) antibody. Oligomers and control preparations were either used directly or frozen at $-80^{\circ} \mathrm{C}$ in aliquots and used for up to 4 weeks.

\section{Morris water maze}

The spatial Morris water maze (MWM) task was performed as described previously [32, 49-51]. Seven to eight WT (TgA ${ }^{-}-5 x F A{ }^{-}$, one mouse excluded for reversal phase of task), twelve 5xFAD and twelve TgA-5xFAD male mice were used for behavioural analyses. No a priori power estimates were used, but numbers were chosen based on previous experiments following the MWM protocol [32, 49-51]. We used 6-month-old mice because in previous experiments $5 x F A D$ male mice at this age have been shown to cross the platform less, take longer to find the platform and have spatial reference memory deficits compared to WT C57BL6 controls [52].

Experiments were performed at $22-24{ }^{\circ} \mathrm{C}$ in a room with two large lamps next to the pool illuminating the room, and animals were acclimated for approximately 30 min before task initiation. Performance on the MWM was recorded with ANY-Maze Software. The researcher 
was blind to genotypes during experiments, however, analyses for reference memory, reversal memory and acquisition of the task were not done blindly. Animals were trained for four days, four trials per day, to find the platform in the water tank. On the fifth day of testing (probe trial), the platform was removed and the percentage of time during $60 \mathrm{~s}$ that a mouse spent in each quadrant was analyzed, and this is referred to as reference memory/probe trial. Two days following the acquisition and memory testing phase, animals started the reversal phase of the task, in which the platform was moved to a different quadrant. Learning to acquire the new position of the platform was assessed again over four days, and reversal memory after the platform was removed on the fifth day was analyzed as described above.

\section{Western blotting}

After mice (3-5-month-old, male) were anesthetized with ketamine $(100 \mathrm{mg} / \mathrm{kg})$-xylazine $(20 \mathrm{mg} / \mathrm{kg})$, the animals were perfused with ice cold PBS and one whole hemisphere was collected for neuropathology (procedure described below) and the other hemisphere was dissected for Western Blotting or ELISA. Tissue was dissected on ice to isolate cortex and hippocampus, then flash frozen on dry ice before transferred to $-80^{\circ} \mathrm{C}$ for long-term storage. Western blotting was performed as described previously $[32,49,53]$. Briefly, tissue was weighed and homogenized in ice cold RIPA buffer (50 mM Tris, $150 \mathrm{mM} \mathrm{NaCl}, 0.1 \%$ SDS, $0.5 \%$ Sodium Deoxycholate, $1 \%$ Triton-X 100, pH 8.0) with phosphatase inhibitors $(1 \mathrm{mM} \mathrm{NaF}$ and $0.1 \mathrm{mM}$ $\left.\mathrm{Na}_{3} \mathrm{VO}_{4}\right)$ and protease inhibitor cocktail (1:100, Catalog\# 539134-1SET, Calbiochem), followed by cold sonication $3 \times 7 \mathrm{~s}$. Homogenates were then rocked at $4^{\circ} \mathrm{C}$ for $20 \mathrm{~min}$, then centrifuged at $10,000 \mathrm{x} \mathrm{g}$ for $20 \mathrm{~min}$ at $4{ }^{\circ} \mathrm{C}$ to isolate protein. Protein was quantified using BioRad DC Protein assay (Catalog\# 5000112, BioRad). 5-80 $\mu$ g of protein was loaded onto $4-12 \%$ Bis-Tris Plus Gels (ThermoFisher) or on $13.5 \%$ Tris-Tricine Gels. Protein was transferred onto PVDF membranes (Catalog \#: IVPH00010, EMD Millipore) by BioRad Semi-Dry Transfer Trans-Blot Turbo system. Primary antibodies used for immunoblotting: anti-STI1 (1:5000, in-house antibody generated by Bethyl Laboratories Montgomery, USA), anti-Hsp90 $\beta$ (1:1000, Cat\#5087, Cell Signaling, RRID:AB_10548761), anti-Hsp70 (1:1000, Cat\#ab2787, Abcam, RRID:AB_303300), anti-APP (C-terminal; 1:1000, Cat\#ab32136, Abcam, RRID:AB_2289606), anti-APP (Nterminal; 1:1000, Cat\#ab2072, Abcam, RRID:AB_302812), anti-BACE1 (1:1000, Cat\#5606, Cell Signaling, AB_ 1903900), anti-MMP2 (1:1000, Cat\#ab37150, Abcam, RRID:AB_881512), Anti-CD10 (Neprilysin: 1:1000, Cat\#ab951, Abcam, RRID:AB_2146533), Anti-Insulin Degrading Enzyme (1:1000, Cat\#ab32216, Abcam, RRID:AB 775686), anti-PSD95 (1:1000, Cat\#MA1046, Pierce, RRID:
AB_2092361), anti-Synaptophysin (1:1000, Cat\#5461, Cell Signaling, RRID:AB_10698743). Loading control used was anti- $\beta$-actin (1:25000, Cat\#A3854, Sigma, RRID:AB 262011) and secondary antibodies were sheep anti-mouse HRP (1:5000, Cat\#SAB3701095, Sigma, RRID: N/A) and goat anti-rabbit HRP (1:10000, Cat\#170-6515, BioRad, RRID:AB_11125142). Proteins were visualized using chemiluminescence on FluoroChemQ chemiluminescent exposure system (Alpha Innotech) or ChemiDoc MP Imaging System (BioRad) and analyzed using their respective software (Alpha Innotech and Image Lab).

\section{Biochemical fractionation to isolate Tris-soluble, membrane bound and insoluble APP}

Tris-soluble, membrane-bound and insoluble fractions were isolated as described previously [50, 54]. Cortices from 3 to 5-month-old male mice perfused with ice cold phosphate-buffered saline (PBS), pH 7.4, were used for experiments. Tissue was weighed and homogenized using Wheaton Overhead Stirrer (Cat\#903475) in 6.5× the weight of each sample in $20 \mathrm{mM}$ Tris- $\mathrm{HCl}(\mathrm{pH} 8.5)$ with protease and phosphatase inhibitors. Homogenates were centrifuged for $1 \mathrm{~h}$ at $135,000 \mathrm{x}$ g at $4{ }^{\circ} \mathrm{C}$. Supernatant was collected as Tris-soluble fraction and stored for ELISA at $-80^{\circ} \mathrm{C}$. Next, tissue was homogenized and resuspended in $10 \mathrm{mM}$ Tris, $150 \mathrm{mM} \mathrm{NaCl}, 0.02 \%$ Triton-X 100 (pH 7.6) with protease and phosphatase inhibitors, $15 \times$ the weight of pellet, using Cordless Motor and Pestle (Cat\#47747-370, VWR). Samples were centrifuged at $100,000 \mathrm{xg}$ for $1 \mathrm{~h}$ at $4{ }^{\circ} \mathrm{C}$. Supernatant was collected as the membrane-bound fraction and stored immediately at $-80^{\circ} \mathrm{C}$ for Western blotting. Finally, pellet was resuspended and homogenized in $1 \mathrm{ml}$ of 3 M Guanidinium Hydrochloride $(\mathrm{GHCl}), 50 \mathrm{mM}$ Tris ( $\mathrm{pH}$ 8.0) with protease inhibitors followed by vigorous vortexing and overnight incubation on a tube rotator at $4{ }^{\circ} \mathrm{C}$ to dissolve pellet into solution. This constituted the insoluble APP fraction, which was then stored at $-80^{\circ} \mathrm{C}$ for use in ELISA.

\section{Human $A \beta_{1-42}$ ELISA}

ELISA for Tris-soluble and $\mathrm{GHCl}$ insoluble $A \beta$ was performed as described previously [50, 54, 55] following manufacturer's instructions (Catalog\# KHB3441, ThermoFisher).

\section{Histological processing}

After mice were anesthetized with ketamine $(100 \mathrm{mg} /$ $\mathrm{kg})$-xylazine $(20 \mathrm{mg} / \mathrm{kg})$ and then transcardially perfused with ice cold PBS ( $\mathrm{pH} 7.4$ ), one hemisphere was placed in $4 \%$ paraformaldehyde for $24 \mathrm{~h}$, then in $15,20 \%$ then $30 \%$ sucrose for $24 \mathrm{~h}$ at $4{ }^{\circ} \mathrm{C}$ before being embedded in OCT (Thermo Scientific Shandon Cryomatrix embedding resin, Catalog \# 67-690-06), frozen on dry ice then 
stored at $-80{ }^{\circ} \mathrm{C}$. Frozen tissue blocks were acclimated to $-20^{\circ} \mathrm{C}$ for at least 30 mins prior to cryosectioning on Leica CM350 or CM1950 Cryostat, and $30 \mu \mathrm{M}$ sections were collected and stored free floating in PBS $+0.02 \%$ sodium azide at $4{ }^{\circ} \mathrm{C}$ until use.

\section{Congo red}

Free floating sagittal sections $(30 \mu \mathrm{m})$ were mounted onto SuperFrost Plus Slides (Fisher), dried at RT, then stained following IHC World "Modified High pH Congo Red Staining Protocol for Amyloid" [50]. Briefly, sections were incubated in filtered $0.3 \%$ Congo Red Solution (dissolved in $80 \%$ ethanol with $1 \%$ sodium hydroxide) for $10 \mathrm{~min}$ in the dark. Sections were rinsed in distilled water until water ran clear, followed by 10 dips in alkaline alcohol ( $1 \%$ sodium hydroxide in $50 \%$ ethanol) solution, then water wash. Sections were counterstained in Harris Hematoxylin (Cat\#10143-610, VWR) for $45 \mathrm{~s}$, rinsed in water for $2 \mathrm{~min}$ and then rocked in tap water with 5 drops of concentrated $(14.5 \mathrm{M})$ ammonium hydroxide until sections turned blue. After another water rinse, sections were dehydrated in 70, 95 and 100\% ethanol, followed by two 100\% xylene washes and slides were cover-slipped using DPX mounting media (Catalog\# 44581, Sigma). Sections were imaged using Zeiss Axioskop Optical Microscope at 20X magnification, with two images captured sequentially (non-overlapping) along the dentate gyrus (from the apex to the hilus/opening of the blades), and one image each along the CA3, CA1 and subiculum. Sections were at least $120 \mu \mathrm{m}$ apart, with 4-6 sections per animal being imaged and quantified. Experimenters were blind to genotype during image collection and analyses. Images were analyzed in Fiji (ImageJ, NIH), using the same parameters for each image and genotype. Images collected were converted to 8-bit, background was subtracted to create a light background and separate colours. Images were then deconvoluted using the H-PAS colour deconvolution function to analyze Congo Red staining more accurately. The percent area was averaged across the whole hippocampus (averaging the values obtained from each separate hippocampal sub-region) and then 4-6 sections per mouse were averaged, with 4-5 mice per genotype.

\section{Thioflavin S staining}

Thioflavin staining was performed as described previously [54], following the AlzForum protocol (Alzforum https://www.alzforum.org/protocols/thioflavin-s-staining) with some modifications. Briefly, mounted $30 \mu \mathrm{m}$ sagittal sections were incubated with $1 \%$ Thioflavin S (dissolved in 50\% ethanol) for $8 \mathrm{~min}$ in the dark at room temperature. Upon removal of stain, sections were washed twice with $80 \%$ ethanol, $3 \mathrm{~min}$ each, then once with 95\% ethanol for another $3 \mathrm{~min}$. Sections were then re-hydrated with three distilled water washes. Sections were mounted using Immumount (Cat\#9990412, ThermoScientific, Shandon) and imaged using LSM Meta 510 confocal microscope equipped with a 10X/0.3 Plan Neofluar objective. One-two sequential (non-overlapping) images along the dentate gyrus were captured, as well as 1 image each of the CA3, CA1 and posterior CA1/subiculum areas. For analyses, images were converted to 8-bit in Fiji, then a deconvoluted thresholded image was obtained with a white background and black plaques. The percent area of the plaques was measured using the Fiji Measure plugin, averaged across the whole hippocampus (averaging the values obtained from each separate hippocampal sub-region image), and then 4-6 sections per mouse of each genotype were averaged. Sections from 4 to 5 mice per genotype were used, and experimenters were blind to genotype during image collection and analyses.

\section{Silver staining}

Silver staining was performed as described previously. Using 6-well plates and net-wells, free-floating sections were stained with the NeuroSilver ${ }^{\mathrm{TM}}$ staining kit II (Catalog\#: PK301, FD NeuroTechnologies, Inc., Baltimore, USA) following manufacturer's instructions. This kit labels degenerating neuronal bodies, processes and terminals. Images were taken using Zeiss Axioskop Optical Microscope at 20X magnification, with two images being taken along the dentate gyrus, from the apex to the hilus/opening of the blades, one image each of the CA3, CA1 and subiculum. At least 4 sections from 4 to 5 animals/genotype were stained and sections selected were at least $120 \mu \mathrm{m}$ apart. Using ImageJ (Fiji) Software (NIH), images were converted to 8 bit and thresholded to make the silver particles black and background white (Circularity of 0-0.65). Particles were numbered and averaged for each animal. The same parameters were used for each section, animal and both genotypes.

\section{Immunofluorescence}

Immunostaining for $A \beta$ in mouse tissue was performed as described previously [54]. Sagittal $30 \mu \mathrm{m}$ sections were mounted onto Superfrost Plus slides and after drying, sections were boiled in $10 \mathrm{mM}$ sodium citrate (pH 6.1) for $20 \mathrm{~min}$ in antigen retriever at $95^{\circ} \mathrm{C}$, and then cooled on ice to RT for $1 \mathrm{~h}$. Sections were then washed twice for $5 \mathrm{~min}$ in $1 \mathrm{X}$ Tris-buffered saline (TBS), pH 7.5. Next, sections were permeabilized by incubating in $0.3 \%$ Triton-X in TBS, pH 7.5, twice for 5 min and blocked in $2 \%$ horse serum (HS), $2 \%$ normal goat serum (NGS), $1 \%$ BSA, $0.3 \%$ Triton-X in TBS, $\mathrm{pH} 7.5$, for $90 \mathrm{~min}$ at room temperature. Sections were then incubated with primary antibody anti- $\beta$-amyloid (6E10, Cat\#803001, 1:200, Biolegend) alone, or with anti-STI1 (Bethyl Laboratories, 1: 
400), anti-Iba1 (Cat\#:019-19,741, 1:1000, Wako, RRID: AB_839504) or anti-Hsp90 $\beta$ (Cat\#5087, 1:50, Cell Signaling, RRID:AB_10548761). The following day after $\sim 18 \mathrm{~h}$ incubation with primary antibody at $4{ }^{\circ} \mathrm{C}$, sections were washed twice with TBS, 5 min each, then incubated with secondary donkey anti-rabbit Alexa Fluor 647 (1: 500, Cat\#A-31573, ThermoFisher) and/or goat antimouse Alexa Fluor 488 (1:500, Catalog\# A-11001, ThermoFisher) antibodies for $2.5-3.5 \mathrm{~h}$ at $4{ }^{\circ} \mathrm{C}$. Sections were washed three times with TBS then incubated with Hoechst 33342 (Cat\#62249, ThermoFisher) for $15 \mathrm{~min}$, rinsed three times, then mounted on slides using Immumount. For STI1 labelling with A $\beta$, prior to nuclear labelling, sections were incubated with Vector TrueVIEW $^{\mathrm{Tm}}$ Autofluorescence Quenching Kit (Cat\#VECTSP8400, Vector) following manufacturer's instructions. Immunofluorescent labelling for cleaved caspase-3 was performed as described previously [50]. Percent area analyses for $A \beta$ immunoreactivity across the whole hippocampus were performed as described above for Thioflavin S staining. Images were captured using Leica TCS SP8 (Leica Microsystems Inc., Ontario, Canada) confocal system at $10 \mathrm{X}$ objective (N.A. 0.4) for A $\beta$ percent area experiments, at 20X objective (N.A. of 0.75) for CC-3 immunostaining, and at 63X (N.A. of 1.4) for A $\beta$, STI1, Hsp90 $\beta$ and Iba1 imaging.

For analyses of Iba1+ microglia in contact with $A \beta$ plaques, two sequential non-overlapping images along the dentate gyrus were captured, as well as 1 image of the CA3, 1 image of the CA1 and 1 image of the posterior CA1/subiculum. The number of microglia in each field of view was counted, considering a total (those surrounding/touching plaques and not associated (near/in contact) with plaques), and those only in contact with plaques. The number of $A \beta$ plaques in each imaged subfield was counted. The sum number of plaqueassociated microglia (those with processes or cell body seen touching plaque or no more than $10 \mu \mathrm{m}$ from plaque) averaged per section and the average number of microglia around plaques were estimated. Images were captured using the using Leica TCS SP8 (Leica Microsystems Inc., Ontario, Canada) confocal system (40X objective, N.A. of 1.3).

\section{Human AD tissue and immunofluorescence}

Blocks of parietal and temporal human brain tissue from 5 patients with a Neuropathological diagnosis of AD (all Braak stage 5-6: 3 male/2 female, average age 82 ; 75 year old (y/o) male, 88 y/o male, 89 y/o male, 80 y/o female, 82 y/o female), were embedded in paraffin and sections were cut at $5 \mu \mathrm{m}$ using Microm HM335E Microtome, then deparaffinized using the Leica Autostainer XL. Sections were then left rocking in TBS, pH 7.6 for $2 \mathrm{~h}$. Antigen retrieval was performed by boiling sections at $95^{\circ} \mathrm{C}$ in $10 \mathrm{mM}$ citrate buffer $+0.05 \%$ Tween ( $\mathrm{pH}$ 6.0) for 20 min then cooled on ice in the same buffer for $1 \mathrm{~h}$. Additionally, sections were incubated in $70 \%$ formic acid for 10 min then rinsed with $10 \%$ formic acid. Sections were rinsed with water, washed twice with TBS for $5 \mathrm{~min}$. Next, tissue was permeabilized in TBS with $0.3 \%$ Triton $\mathrm{X}-100$ for $5 \mathrm{~min}$, followed by a $1.5 \mathrm{~h}$ blocking at RT in $2 \%$ horse serum, $2 \%$ NGS, $1 \%$ BSA, $0.3 \%$ Triton X-100 in TBS. Sections were incubated overnight at $4{ }^{\circ} \mathrm{C}$ with primary antibodies anti-STI1 (1:300, Bethyl) and anti6E10 (1:100, Biolegend) in 1\% horse serum, $1 \%$ NGS, $0.5 \%$ BSA and $0.1 \%$ Triton X-100 in TBS. The following day, sections were left at RT for $\sim 2 \mathrm{~h}$ in primary antibody, then washed twice with TBS with $0.1 \%$ Triton X100 , followed by incubation with secondary antibodies donkey anti-rabbit Alexa Fluor 647 (Cat\#A-31573, ThermoFisher, RRID:AB_2536183) and goat anti-mouse Alexa Fluor 488 (Cat\#A-11001, ThermoFisher, RRID: AB_2534069). Sections were incubated with secondary antibodies for $4 \mathrm{~h}$ at $4{ }^{\circ} \mathrm{C}$, then washed three times with TBS. After washing, the sections were then incubated for $30 \mathrm{~s}$ with TrueBlack Lipofuscin Autofluorescence Quencher according to manufacturer's instructions (Cat\#10119-144, Biotium), rinsed three times with TBS, and mounted on slides with Immumount. Images were obtained using Olympus FV1000 confocal microscope at $63 \mathrm{X}$ (N.A. of 1.35) at 1.5-2.5X zoom. Representative images shown are all from the same magnification and zoom.

\section{Statistical analysis}

For C. elegans experiments, all experiments were repeated at least three times (3 biological replicates). Data are presented as mean values $+/-$ SEM. $p$-values for two group comparisons were calculated using student's ttest. $\left(^{*}\right)$ denotes $p<0.05$; $\left.{ }^{* *}\right)$ denotes $p<0.01$ and $\left({ }^{* * *}\right)$ denotes $p<0.0001$. To compare two independent populations (paralysis assays) p-values were calculated using the Wilcoxon Mann-Whitney rank sum test. For mouse pathology and Western blot experiments, data were analyzed using student's t-test, except for APP processing in which Two-Way ANOVA was used. For MWM TwoWay ANOVA with Repeated Measures were used to analyze datasets, with appropriate post-hoc analyses as required. Prism 7 software was used for all statistical analyses.

\section{Results}

STI1 and Hsp90 protect C. elegans and mouse primary hippocampal neurons against Amyloid- $\beta$ toxicity.

We have previously shown that treatment with recombinant STI1 can protect cultured neurons from $\mathrm{A} \beta \mathrm{O}$ induced cell death, by preventing $\mathrm{A} \beta \mathrm{O}$ mal-adaptative signalling via the prion protein [29]. To investigate whether 
increased endogenous expression of STI1 can protect mammalian neurons from $\mathrm{A} \beta \mathrm{O}$ toxicity, we derived primary hippocampal neuronal cultures from E17.5 mouse wild-type (WT) control embryos and those endogenously overexpressing STI1 (mouse line named TgA; overexpressing STI1 3-fold [25]). The cultures were subjected to increasing concentrations of $\mathrm{A} \beta \mathrm{Os}$ for $48 \mathrm{~h}$. At $0.5 \mu \mathrm{M}$ and $1.0 \mu \mathrm{M}$ of $\mathrm{A} \beta \mathrm{O}$, neuronal cultures from TgA mice died significantly less than control cultures (Fig. 1a, $p=0.025$, $p=0.019$ for $0.5 \mu \mathrm{M}$ and $1.0 \mu \mathrm{M}$, respectively), determined using the Live/Dead Assay. Likewise, using the LDH assay, TgA neuronal cultures released less $\mathrm{LDH}$ (indicator of dying cells) than control neurons at $1.0 \mu \mathrm{M}$ of $\mathrm{A} \beta \mathrm{Os}$ (Fig. 1b, $p=0.0017)$. Since exogenous recombinant STI1 and $\operatorname{PrP}^{\mathrm{C}}$ interaction blocks $\mathrm{A} \beta \mathrm{O}$ toxicity [29], we tested whether secreted STI1 in TgA primary neurons was responsible for increased neuronal resilience against $A \beta O$ s. We blocked extracellular STI1 signalling with a validated STI1 antibody [25] and assessed neuronal survival in the presence of $\mathrm{A} \beta \mathrm{Os}$ using the Live/Dead Viability and Toxicity kit. We found that treating control or TgA cultures with the anti-STI1 antibody had no significant effect on cell viability (Fig. 1c, $p>0.1$ ), in cultures pre-treated with $1 \mu \mathrm{M}$ A $\beta \mathrm{Os}$, TgA neuronal cultures had significantly less cell death than control cultures (Fig. 1c, $p=0.033$ ). However, WT and TgA neurons treated with $\mathrm{A} \beta \mathrm{O}$ s and the

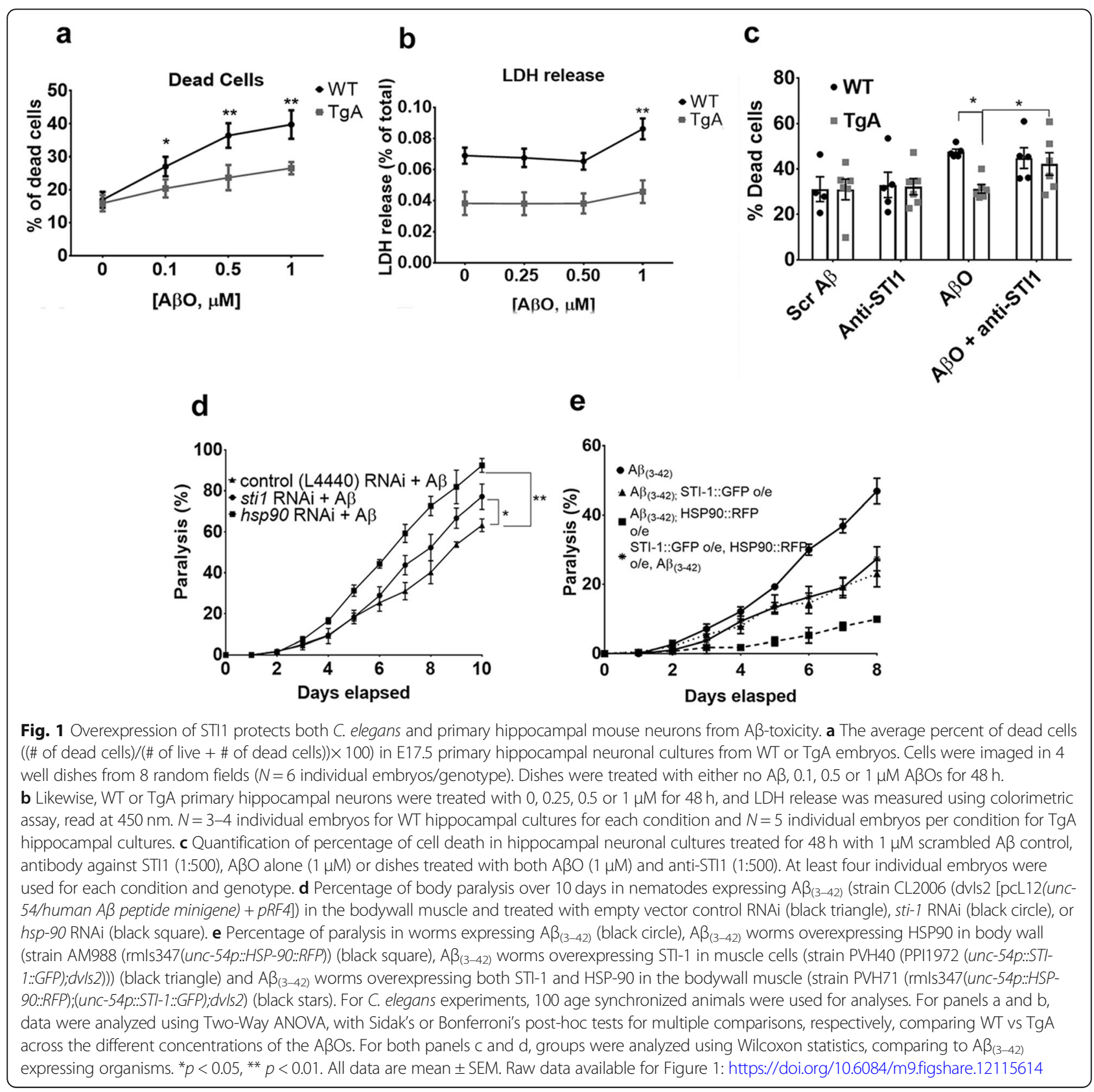


anti-STI1 antibody displayed elevated levels of cell death, and $\operatorname{TgA}$ neurons were no longer resilient against $\mathrm{A} \beta \mathrm{O}$ insult (Fig. 1c, p > 0.1).

In addition to preventing toxic A $\beta \mathrm{O}$ signalling [29], STI1 can modulate proteostasis $[32,42]$. In yeast, Hsp70 requires STI1 for the reorganization of amyloid-like proteins into toxicity buffering foci [35], and Hsp70 and Hsp90, which are bridged by STI1, can decrease $A \beta$ fibril formation and aggregation [56]. Hence, to initially study STI1 and Hsp90 mediation of $A \beta$ proteotoxicity, we used C. elegans, an organism that does not express the prion protein or its homologues, but has been shown to require STI1 for protection and reduction of amyloid aggregates [30].

Previous work has shown that knockdown of STI-1 and HSP-90 in C. elegans increases A $\beta$ toxicity [30]. We repeated and expanded these experiments, and confirmed in C. elegans expressing $\mathrm{A} \beta_{(3-42)}$ that RNAi-mediated knockdown of sti-1 or hsp-90 significantly reduced motility compared to worms only expressing $A \beta_{(3-42)}$ over 10 days (Fig. $1 \mathrm{~d}, p=$ $0.0195, p=0.0078$, for $s t i-1$ and $h s p-90$, respectively). Next, we tested whether overexpression of STI-1 and HSP-90 in worms could reduce $\mathrm{A} \beta$-induced paralysis. We found that worms overexpressing HSP-90 seven-fold (C. elegans homolog: $D A F-21 / H S P-90, A \beta_{(3-42)}$; HSP-90::RFP) were less paralysed than $A \beta_{(3-42)}$ worms (Fig. 1e, $p=0.016$ ).
Furthermore, worms overexpressing STI-1 two-fold $\left(\mathrm{A} \beta_{(3-42)} ;\right.$ STI-1::GFP) displayed decreased levels of paralysis $(46 \%$ vs $23 \%$ at day $8, \mathrm{p}=0.016$, Fig. 1e). Interestingly, overexpression of both HSP-90 (7-fold) and STI-1 (2 fold; $A \beta_{(3-42)}$; STI-1::GFP; HSP-90::RFP) alleviated paralysis to a similar degree as overexpression of STI- 1 alone ( $46 \%$ vs $27 \%$ at day $8, \mathrm{p}=0.016)$, and showed a lesser effect than overexpression of HSP-90 by itself. Hence, in a genetic worm model of A $\beta$ toxicity, both STI-1 and HSP-90 have protective effects, although their effects were not synergistic.

\section{Elevated amyloid deposition in 5xFAD mice overexpressing STI1}

To test whether the observations from cultured neurons and $C$. elegans occur in vivo in an AD model, we crossed the $5 x F A D$ mouse line with the STI1 overexpressing mice, TgA. We compared the changes in TgA-5xFAD mice with their littermate controls 5xFAD for all subsequent experiments. We first confirmed that STI1 was indeed overexpressed 3-fold as previously reported in the original TgA line (Fig. 2). Similar to what we observed in the original TgA mice (C57BL/6 background) [49], the constitutive Hsp90 isoform, Hsp90 3 , was increased in the TgA-5xFAD mice in comparison to 5xFAD littermate controls (Fig. 2a,

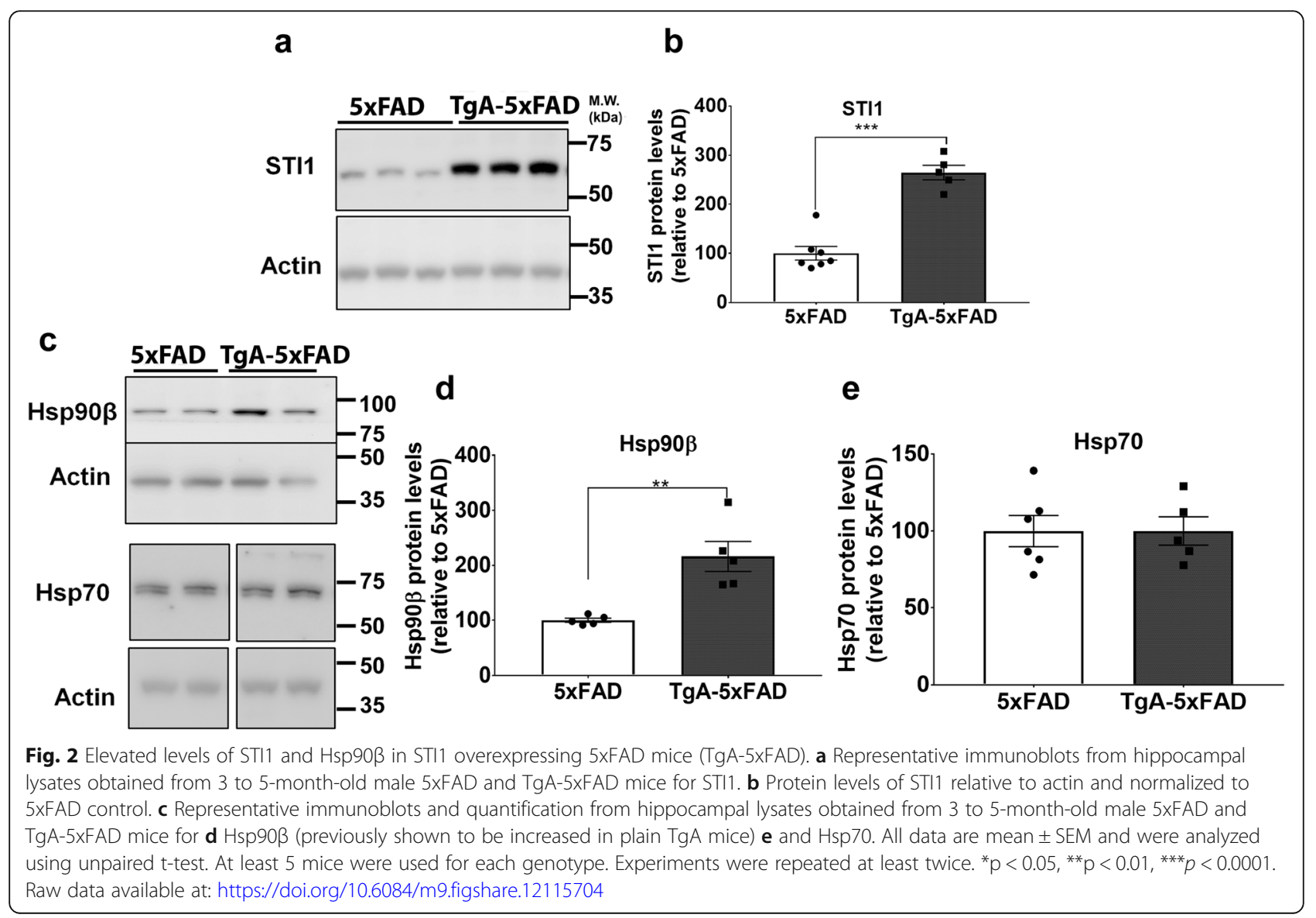


b, $p<0.0001$, Fig. 2c, d, $p=0.027)$. The elevated levels of Hsp90 are likely a compensatory response to increased STI1 levels [49], supporting a strong genetic relationship between Hsp90 and STI1 [57]. Moreover, we found no difference in Hsp70 protein levels between 5xFAD and TgA-5xFAD mice (Fig. 2c, e, $p>0.1$ ).

We then tested whether STI1 overexpression would affect $A \beta$ deposition in 5xFAD mice. Since Hsp90 and Hsp70 reduce $A \beta$ fibrillization [56] and concerted Hsp70-STI1 reorganizes diffuse amyloid [35], we predicted that overexpressing STI1 would reduce $A \beta$ aggregation and toxicity. We first evaluated amyloidosis using Congo Red (labelling $\beta$-pleated sheets in amyloid fibrils [58]), and Thioflavin $S$ (labelling $\beta$-pleated sheets in amyloid fibrils and extracellular neuritic plaques, [59]). Surprisingly, we detected two-fold increase in Congo red amyloid labelling in the hippocampi of 3-5-month-old TgA-5xFAD male mice compared to $5 x F A D$ mice (Fig. 3a, b, $p=0.05$ ). Likewise, when we examined Thioflavin $\mathrm{S}$ staining, there was significantly more amyloid deposition in the hippocampi of TgA-5xFAD mice (Fig. $3 c, d, p=0.032)$. Moreover, $A \beta$ immunoreactivity in TgA-5xFAD mice, detected using an anti-A $\beta$ antibody (6E10, which also labels APP, intracellular and extracellular amyloid), was double that of 5xFAD mice (Fig. 3e, $\mathrm{f}, p=0.047)$. We further evaluated the degree of $\mathrm{A} \beta$ accumulation in 5xFAD and TgA-5xFAD cortices using ELISA against Human $A \beta_{1-42}$. We performed these analyses in the cortex, since both the cortex and hippocampus show considerable $A \beta$ accumulation by $3-5$ months of age in $5 x F A D$ mice [60]. In congruence with the $A \beta$ stains and immunolabelling in hippocampi, we detected an increase in $\mathrm{GHCl}$ insoluble $\mathrm{A} \beta$, but not Tris-Soluble $\mathrm{A} \beta_{1-42}$ levels $(p>0.14$ for soluble and $p=0.0020$ for insoluble, Fig. 3g, h) in TgA-5xFAD male mice compared to $5 x F A D$ controls. Surprisingly, these experiments suggest that STI1 overexpression combined with the increase in Hsp90 levels were linked to early accumulation of $A \beta$ insoluble plaques and augmented levels of insoluble amyloid.

\section{Reduced neuronal resilience in 5xFAD mice overexpressing STI1}

Aggregation of $\mathrm{A} \beta$ in plaques has been proposed to sequester more toxic and soluble $A \beta$ species and serve as a reservoir of inert proteins $[61,62]$. Given that in primary hippocampal neurons STI1 is neuroprotective and reduces A $\beta O$-mediated toxicity (Fig. 1 and [29]) and $C$. elegans experiments showed that STI1 prevented A $\beta$ toxicity in body wall muscle, we performed a number of assays to assess whether 3-5-month-old TgA-5xFAD mice present increased resilience to A $\beta$-toxicity. Firstly, we used the FD NeuroSilver staining kit, which labels degenerating neurons (axons and soma) [50, 63-66]. In the hippocampi of male mice, we found significantly more silver particles in TgA-5xFAD mice, compared to their 5xFAD controls (Fig. 4a, b, $p=0.033$ ), suggesting that STI1 did not confer protection. Synapse loss is also a consequence of $A \beta$ oligomerization and aggregation, thus we evaluated the levels of synaptic proteins, such as the post-synaptic density marker PSD95, and the presynaptic marker synaptophysin [60, 67]. PSD95 was

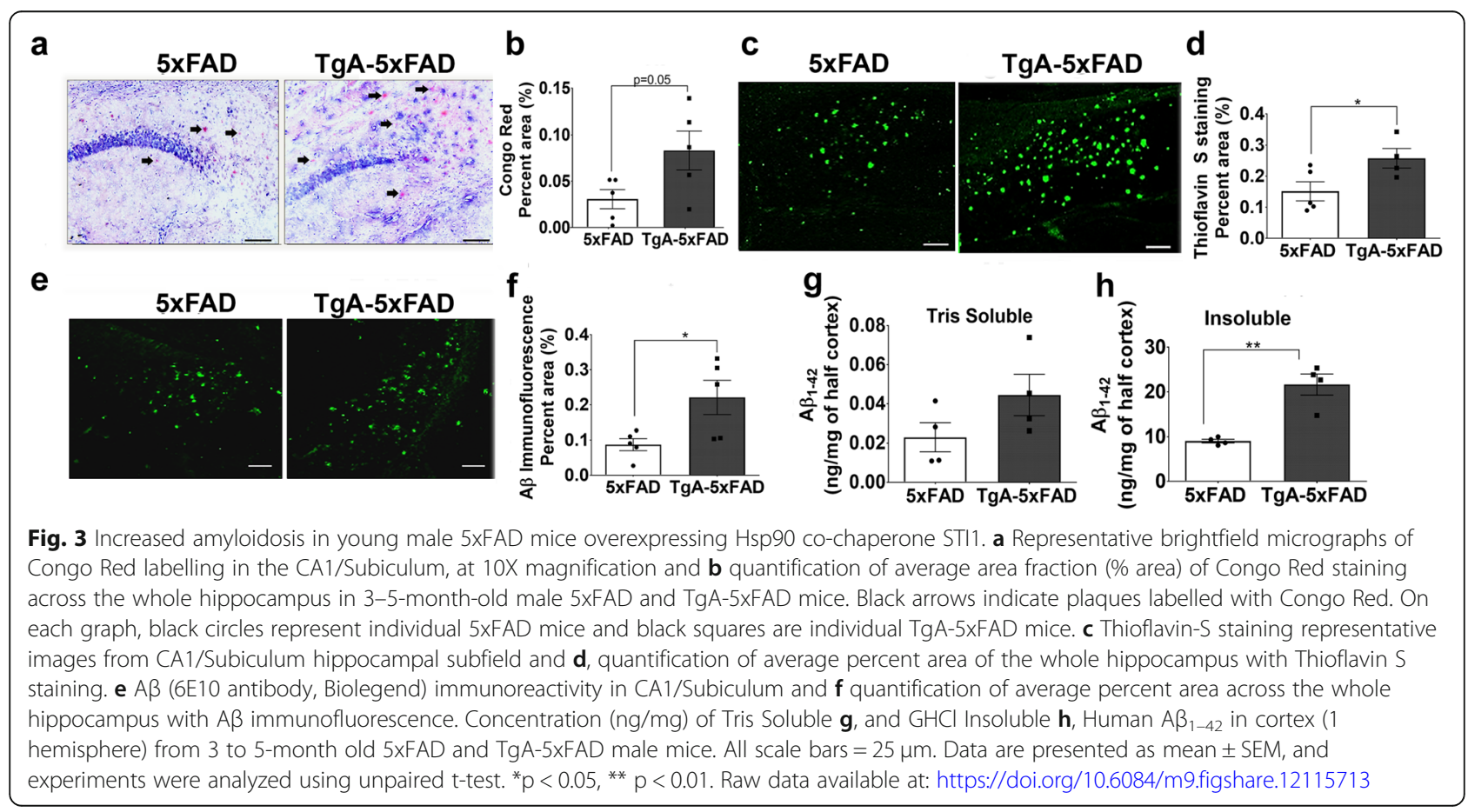




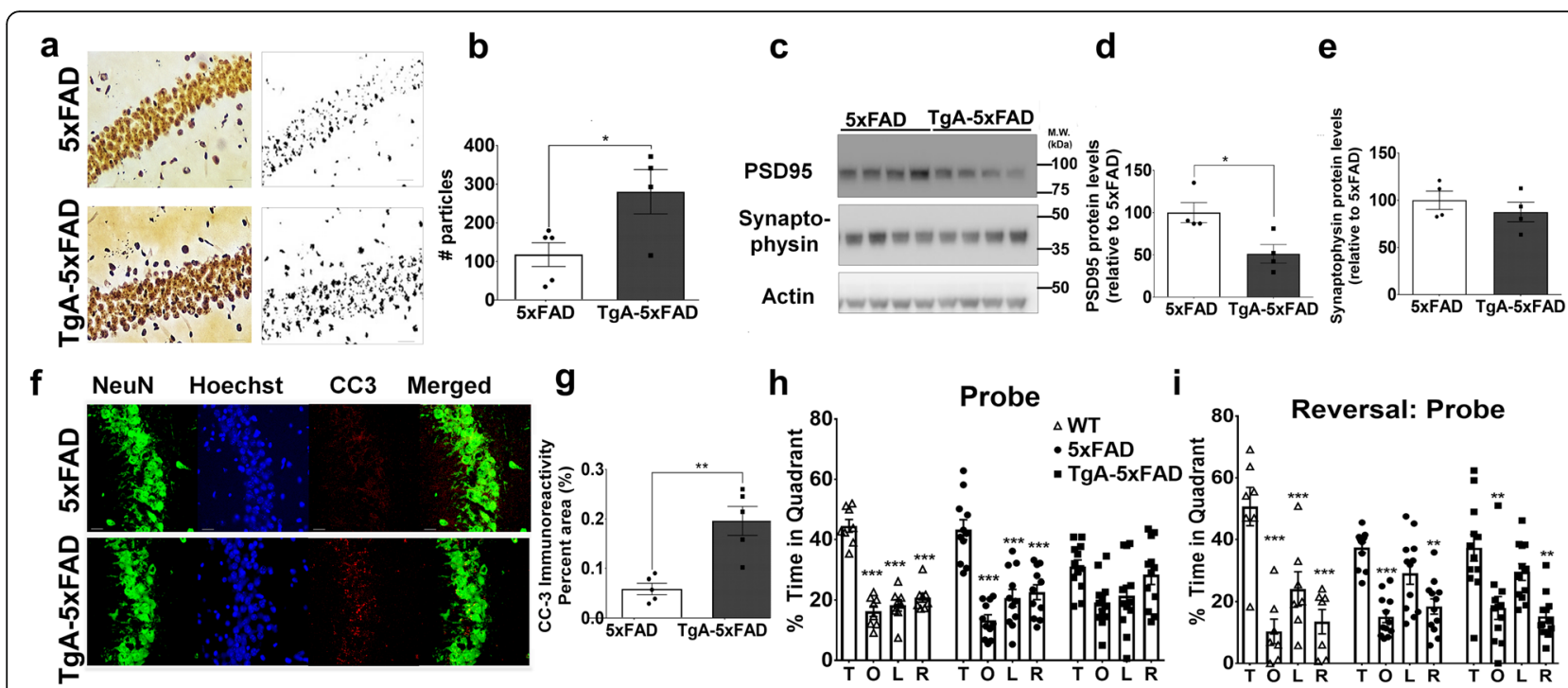

Fig. 4 Increased neurodegeneration and memory deficits in 5XFAD mice overexpressing STI1. a Silver staining representative images (20X magnification) in the CA1 of the hippocampus of 3-5-month old 5xFAD and TgA-5xFAD male mice. Scale bar = 50 $\mu$ m. $\mathbf{b}$ Quantification of number of silver particles (analyzed from thresholded image) across the whole hippocampus in 5xFAD and TgA-5xFAD mice. Three-four sagittal sections from at least four 5xFAD or TgA-5xFAD mice were used for all staining and immunostaining experiments. Black circles depict individual $5 x F A D$ mice and black squares represent individual TgA-5xFAD mice. c Relative protein expression of synaptic markers PSD95 and synaptophysin in cortical lysates from 3 to 5-month old 5xFAD and TgA-5xFAD male mice and $\mathbf{d}$, e densitometric quantification, normalized to actin loading control. $\mathbf{f}$ Cleaved caspase-3 (CC-3) representative images in the CA1 of the hippocampus (scale bars, $25 \mu \mathrm{m}$ ) and $\mathbf{g}$, quantification of CC-3 immunofluorescence, presented as average percent area across the hippocampus. Data are presented as mean \pm SEM, and data presented in $\mathbf{b}$, $\mathbf{d}, \mathbf{g}, \mathbf{e}$ were analyzed using unpaired t-test. ${ }^{*} p<0.05,{ }^{* *} p<0.01$. h Mice were trained for four days on the spatial Morris Water Maze. On the fifth day (Probe trial), the target platform was removed and memory for what quadrant of the pool the target platform was placed, was quantified as the percentage of time in each quadrant. This was assessed in WT (TgA $-5 x F A D-n=7), 5 x F A D(n=12)$ and TgA-5xFAD $(n=12)$ mice. $\mathbf{i}$ Two days following the Probe trial, animals were put on the "reversal" phase of the task, in which the target platform was placed in a different quadrant. Animals were trained for four days then memory was probed again and is denoted as the Reversal: Probe. $T=$ Target, $\mathrm{O}=$ quadrant Opposite to target quadrant, $\mathrm{L}=$ quadrant to the Left of the target quadrant, $\mathrm{R}$ = quadrant to the Right of the target quadrant. All MWM data were analyzed using Two-Way Repeated Measures ANOVA with appropriate Tukey's post hoc multiple comparisons. The * symbols in $\mathbf{h}$, i represent Tukey's post hoc multiple comparisons analysis, comparing percent time spent in the target quadrant (T) comparing the $\mathrm{O}$, L, or R quadrants, within each genotype. ${ }^{*} p<0.05,{ }^{* *} p<0.01,{ }^{* * *} p<0.0001$ for within genotype comparisons for the MWM task. Raw data available at: https://doi.org/10.6084/m9.figshare.12115716

reduced by $50 \%$ in TgA-5xFAD hippocampal tissue (Fig. 4c, d, $p=0.023$ ), however no significant changes were detected between genotypes for synaptophysin at this age (Fig. 4c, e, $p>0.1$ ). Cleaved caspase-3 immunoreactivity was also two-fold higher in the whole hippocampus of TgA-5xFAD mice when compared to littermate 5xFAD mice (Fig. 4f, g, $p=0.002$ ). Taken together, elevation of STI1 (combined with Hsp90) was not neuroprotective, but rather these results suggest increased accumulation of $\mathrm{A} \beta$ and plaque deposition heightened downstream toxicity.

Given the findings that TgA-5xFAD mice have higher levels of amyloid burden and neurotoxicity compared to littermate 5xFAD mice, we next sought to determine if there were any behavioural consequences. We addressed this by assessing mouse learning and memory in the hippocampus-dependent spatial MWM task. We used 6month-old mice and found no significant differences between genotypes (wild type (WT) of mixed B6SJL/C57BL6/ $\mathrm{J}$ background vs $5 \mathrm{xFAD}$ vs TgA-5xFAD) on time to find platform $(p>0.1)$, distance travelled to platform $(\mathrm{p}>0.1)$, mean speed travelled ( $p>0.1$ ), or efficiency of path traveled to platform $(p>0.1)$ during the learning phase of the MWM. During the probe trial, which assesses spatial reference memory, WT and 5xFAD mice spend more time in the target quadrant (Fig. 4h, $p<0.001$ for both WT and 5xFAD comparisons of $\mathrm{T}$ vs $\mathrm{O}$ vs $\mathrm{L}$ vs $\mathrm{R}$ ) and there was no significant difference between time spent in target quadrant between $5 x F A D$ and WT mice (Fig. $4 h, p>0.1$ ), suggesting that at this age the mixed background $5 x F A D$ mice used here did not yet present deficits in reference memory. A similar result was previously reported by Schneider et al. [68] when examining 6-month-old 5xFAD male mice. In contrast, TgA-5xFAD mice did not show preference for the target quadrant ( $\mathrm{T}$ vs $\mathrm{O} p=0.076$, whereas $\mathrm{T}$ vs $\mathrm{L}$ or $\mathrm{T}$ vs $\mathrm{R}$ $\mathrm{p}>0.1)$, and these mice spent significantly less time than WT and $(p=0.011)$ and 5xFAD mice $(p=0.043)$ in the target quadrant. Hence, TgA-5xFAD mice have worse spatial memory than $5 x F A D$ mice. We then performed the reversal component of the task, which assesses behavioural flexibility. This entails changing the target quadrant where the escaping platform is located, training the mice for an 
additional 4 days, and then re-probing the memory on the fifth day for the new target quadrant. In this reversal task, when compared to WT control mice, both $5 x F A D$ mice and TgA-5xFAD mice spent less time in the target quadrant than controls (Fig. 4i, $p=0.03$ and $p=0.029$, respectively), with no difference between $5 \times$ FAD and TgA-5xFAD mice $(p>0.1)$. These results demonstrate that both $5 x F A D$ and TgA-5xFAD mice have deficits in behavioural flexibility in comparison to WT control mice. Interestingly, when preference for the target quadrant was evaluated, both 5xFAD and TgA-5xFAD mice showed increased preference for target quadrant compared to the opposite and right quadrant, suggesting that increased training potentially helped these mutants to solve the task.

\section{Unaltered APP processing but differential expression of enzymes involved in $A \beta$-degradation}

The elevated levels of insoluble $A \beta$ and acceleration of plaque pathology due to increased STI1 levels may be caused by a number of factors. These include increased APP levels, changes in APP metabolites, changes in the enzymes or processes involved in $A \beta$ metabolism, decreased degradation of $A \beta$, or a combination of these factors. Given the diverse roles of intracellular and extracellular STI1 and Hsp90, it is conceivable that more than one mechanism is required to increase insoluble $A \beta$. We evaluated the levels of full-length APP in the membrane bound fraction and found no difference between genotypes for full-length APP, or $\alpha$ and $\beta$ C-terminal fragments (Fig. 5a, b, $p>0.1$ ), suggesting that the increased amyloid deposition observed in Fig. 3 is not due to increased APP levels or processing. In contrast, the levels of enzymes known to regulate $A \beta$ cleavage or degradation were affected by STI1 overexpression. The $\beta$ secretase BACE1, the pro-amyloidogenic enzyme that cleaves APP to form the $\beta$-CTF [69-71] was upregulated three-fold in TgA-5xFAD mice compared to 5xFAD mice (Fig. 5c, d, $p=0.016$ ). We examined the levels of BACE1 in WT vs TgA mice (C57BL/6 background) and found that BACE1 was also significantly elevated in TgA cortical lysates, however only by 1.5 -fold (data not shown). MMP-2, a matrix metalloproteinase known to

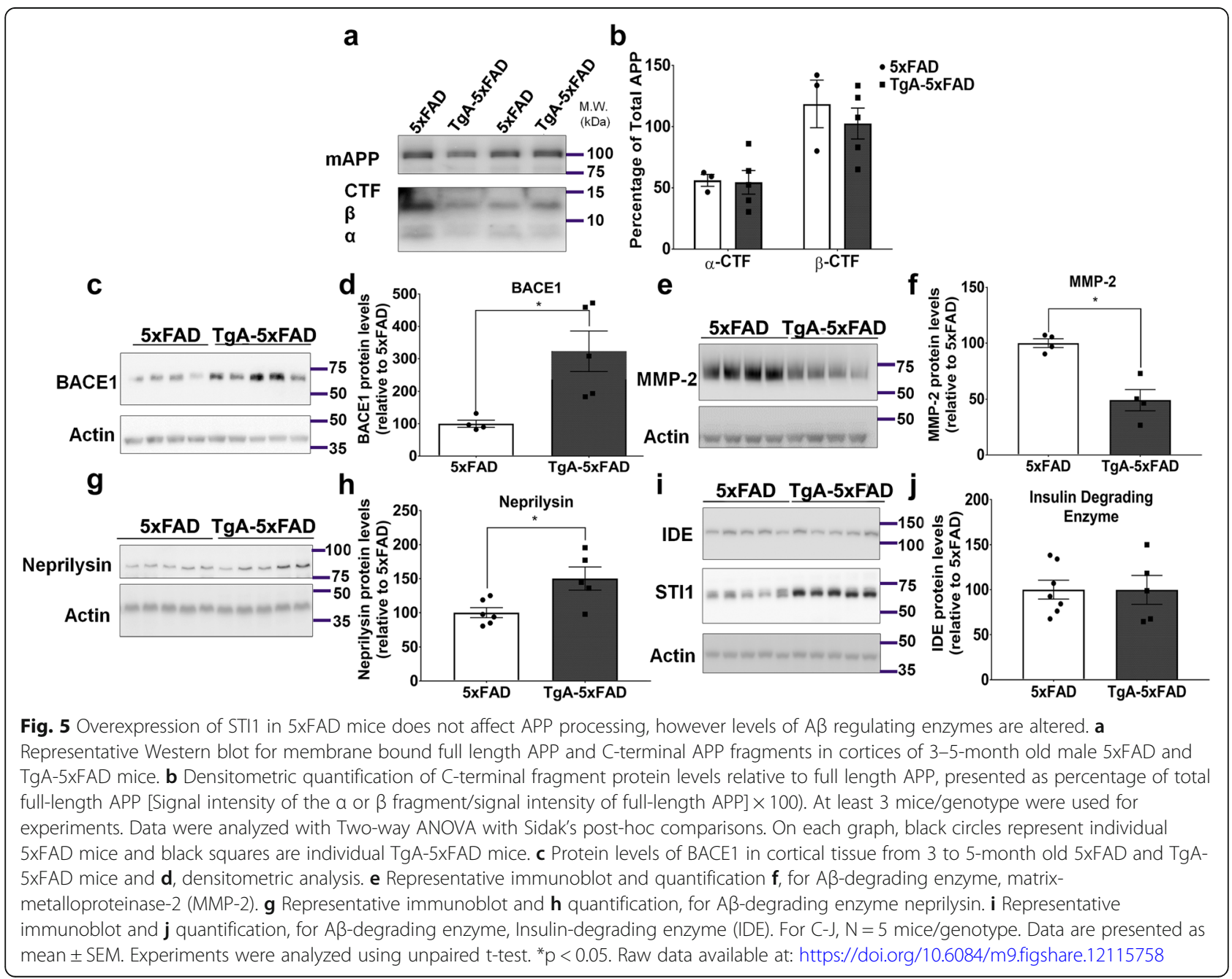


interact with both Hsp90 and STI1 [72, 73] can degrade $\mathrm{A} \beta$, and overexpression of this protein lessened amyloid burden in 5xFAD mice [74]. We found a 50\% reduction in MMP-2 protein levels (antibody for pro and activated forms of MMP-2) in TgA-5xFAD mice compared to $5 \mathrm{xFAD}$ controls (Fig. 5e, f, $p=0.0026$ ). Neprilysin, a wellstudied $A \beta$-degrading enzyme, that is reduced in the hippocampus and cortex of AD mice and humans [75, 76], was slightly increased in TgA-5xFAD mice by about 1.5 -fold, compared to $5 \mathrm{xFAD}$ controls (Fig. $5 \mathrm{~g}, \mathrm{~h}, p=$ 0.018). Lastly, we measured protein levels of insulindegrading enzyme - which is proposed to have chaperone-like activity when degrading $\mathrm{A} \beta$-peptides [77, 78 , and found no difference between TgA-5xFAD and $5 \mathrm{xFAD}$ mice (Fig. $5 \mathrm{i}, \mathrm{j}, p>0.1$ ). These results suggest multiple changes in levels of proteins that participate in amyloid generation and degradation could lead to increased production or decreased clearance of $A \beta$ due to increased STI1 (with the compensatory increase in $\mathrm{Hsp} 90 \beta$ as well).

Another mechanism by which amyloid peptides are degraded, is clearance by microglia $[79,80]$. We addressed whether 3-5-month-old TgA-5xFAD mice could present altered levels of microglia in contact with plaques, since microglia are known to phagocytose $A \beta[79$, 81, 82]. Immunostaining of brain tissue for microglia (Iba1) [83] and $A \beta$ ([6E10, (Fig. 6a)] revealed that a significantly higher number of microglia were closely associated with plaques across the whole hippocampus in TgA-5xFAD vs 5xFAD mice (Fig. 6b, $p=0.023$ ), likely due to the presence of more plaques in TgA-5xFAD mice (representative images of dentate gyrus and subiculum shown in Fig. 6a). However, the average number of microglia in contact with an individual plaque did not differ between 5xFAD and TgA-5xFAD mice (Fig. 6c, $\mathrm{p}>0.1$ ). Relative to neurons, microglia express very low levels of STI1 and Hsp90, as revealed by single-cell RNAseq [84], thus our results suggest that increased levels of STI1 did not impact microgliosis around plaques and that the increased deposition of $A \beta$ is not due to decreased microglia in contact with plaques.

\section{Accumulation of extracellular STI1 and Hsp90 around A $\beta$ dense core, senile plaques}

The above experiments suggest that STI1 potentially favours increased production and decreased degradation of $A \beta$, given the increase in BACE1 and decreased levels of enzymes that can degrade amyloid. STI1, Hsp70 and Hsp90 are secreted by a variety of cells and they are found in the extracellular milieu [25, 85-87], plasma [88] and in principle they could directly contribute to the regulation of $A \beta$ aggregation. Notably, glia secreted Hsp70 reduces neuronal stress in LA-N-5 neuroblastoma cells [89],

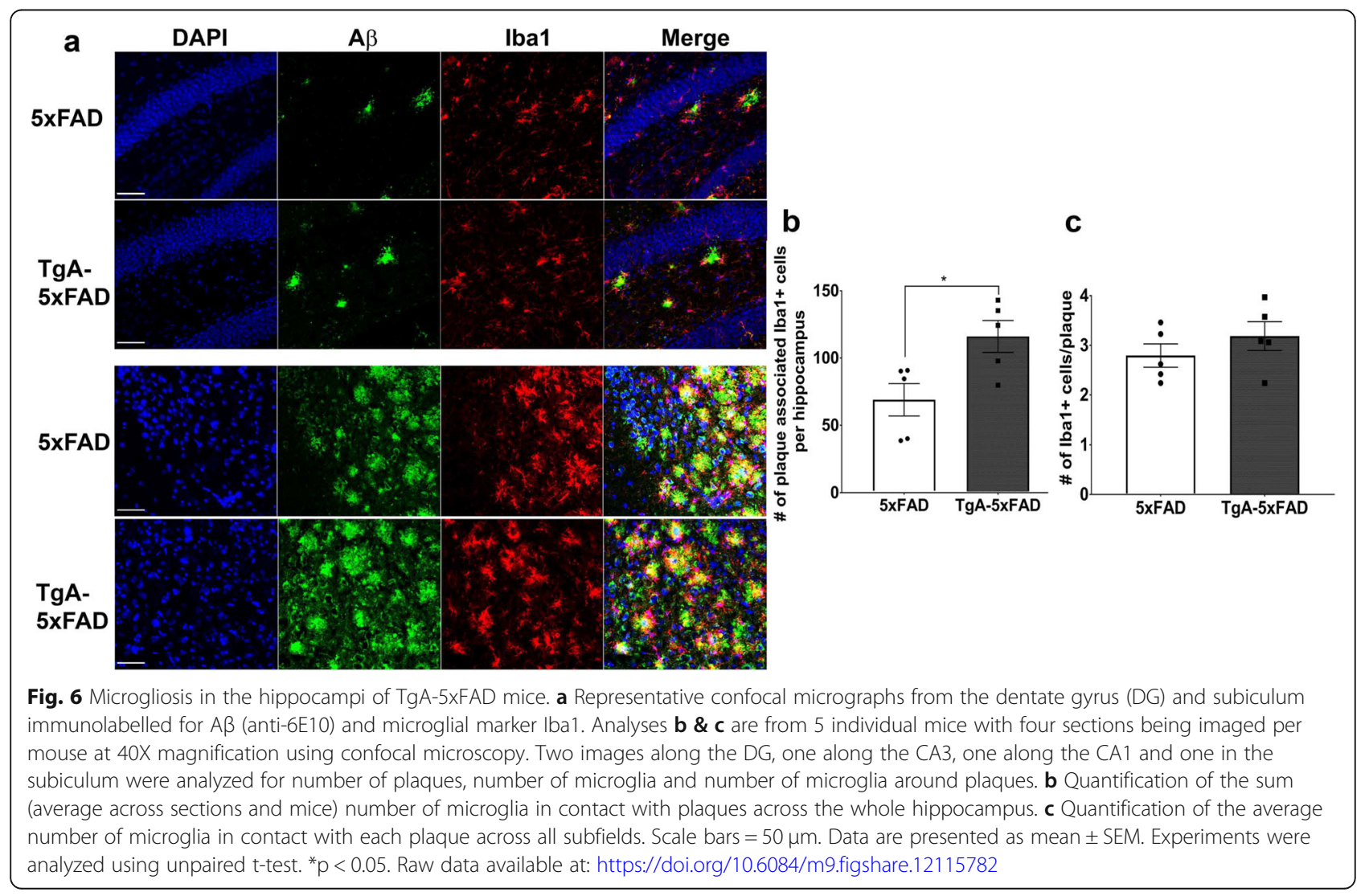


reduces A $\beta$ toxicity in Drosophila [90], and extracellular Hsp70 lessens $A \beta$-oligomerization and attenuates $A \beta$ toxicity in N2A cells [91]. Moreover, Hsp90 has been previously shown to decrease $A \beta$ fibrillization in vitro $[56,92]$. These results may suggest that STI1 could be closely associated with plaques, which we tested by using immunofluorescence confocal microscopy. We performed unbiased, random imaging of STI1 and A $\beta$ plaques in the hippocampus and cortex of 3-5-month-old 5xFAD and TgA-5xFAD mice. We observed STI1 around the dense core of $A \beta$ plaques (anti-6E10 antibody), representing a ring-like structure in both $5 \times \mathrm{xFD}$ and TgA-5xFAD mice (Fig. 7a). STI1 around plaques did not seem to be located in microglia (Fig. 7c), as there is little colocalization between STI1 staining and Iba1+ glial cells, or nuclear marker DAPI (Fig. 7a-c). STI1 co-localization with the A $\beta$ immunoreactive neuritic plaques/cored plaques can be observed in both 5xFAD and TgA-5xFAD mice in both the cortex and hippocampus (Fig. 7a, b), but it is more prominent in TgA-5xFAD. Likewise, we observed co-localization of Hsp90 $\beta$ with dense-core plaques, in both $5 x F A D$ and, increasingly more discernable, in TgA-5xFAD mice (Fig. 7d). These results suggest that extracellular STI1 and Hsp90 $\beta$ can accumulate in $A \beta$ plaques.
Importantly, we verified that STI1 is also present in plaques in human AD brains. Immunofluorescence imaging of STI1 and $A \beta$ in five AD patient brains showed significant STI1 labeling in what seemed to be more mature plaques (a minimum of 5 found in each section) with dense cores of $A \beta$ (Fig. 8a; a minimum of 3 distinct sections labelled and plaques imaged). Conversely, we also observed several examples of less mature plaques (at least 10-20 per brain section) in which STI1 was not accumulated (Fig. 8b). Blood vessels that were positive for A $\beta$ also showed STI1 immunoreactivity (small white filled arrow in Fig. 8a).

\section{Discussion}

The present experiments revealed the relationship between STI1 and Hsp90 in worm and mouse AD models of amyloidosis in vivo. We confirmed and extended previous results demonstrating that in cultured neurons, overexpression of STI1 prevented A $\beta$ toxicity via extracellular mechanisms. We also report an inverse relationship between levels of Hsp90, STI1 and A $\beta$ toxicity in worms, suggesting that increasing the levels of Hsp90 and STI1 is protective.

In contrast, in mammals, endogenous elevation of STI1 and compensatory ectopic increase in Hsp90 $\beta$

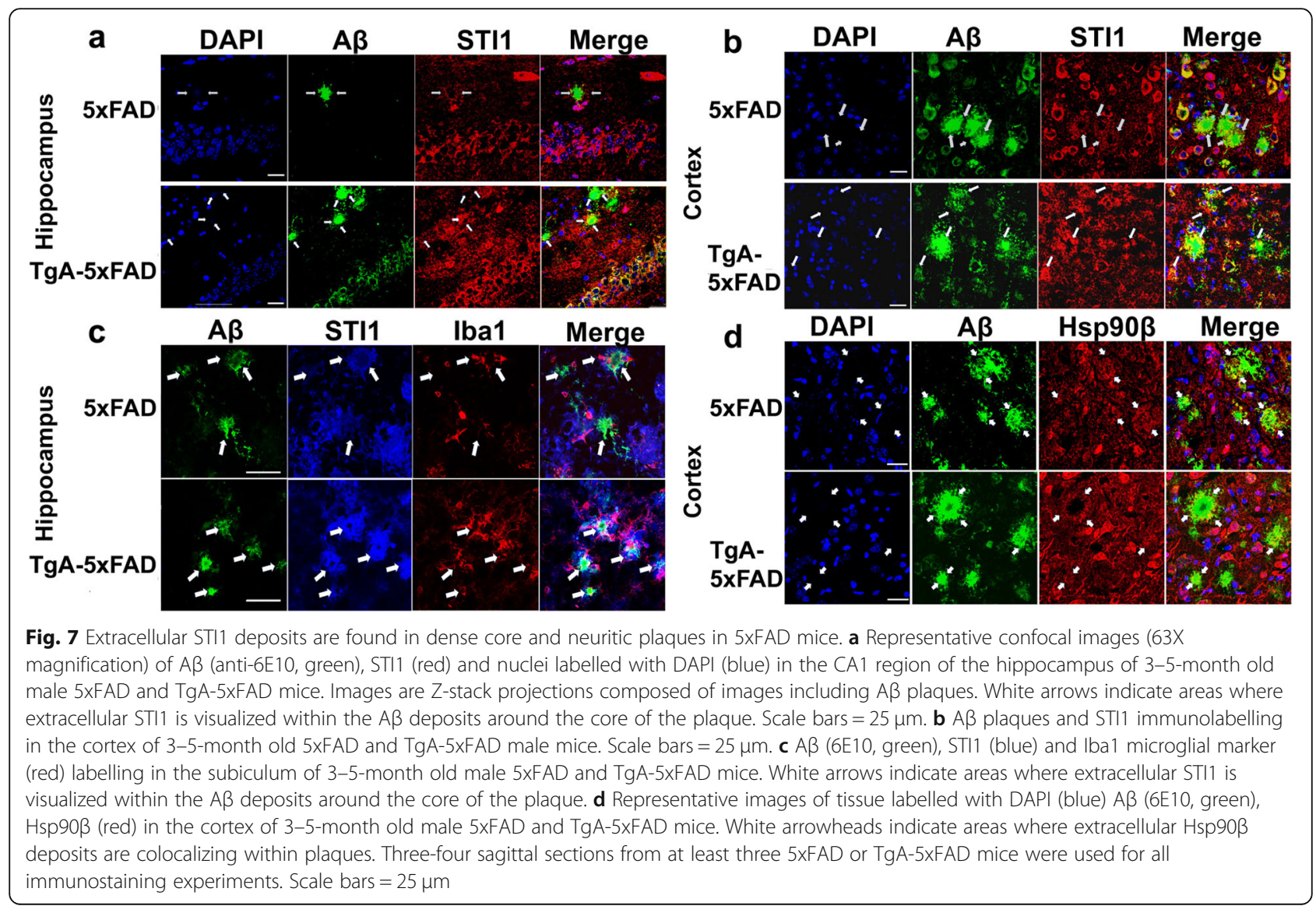




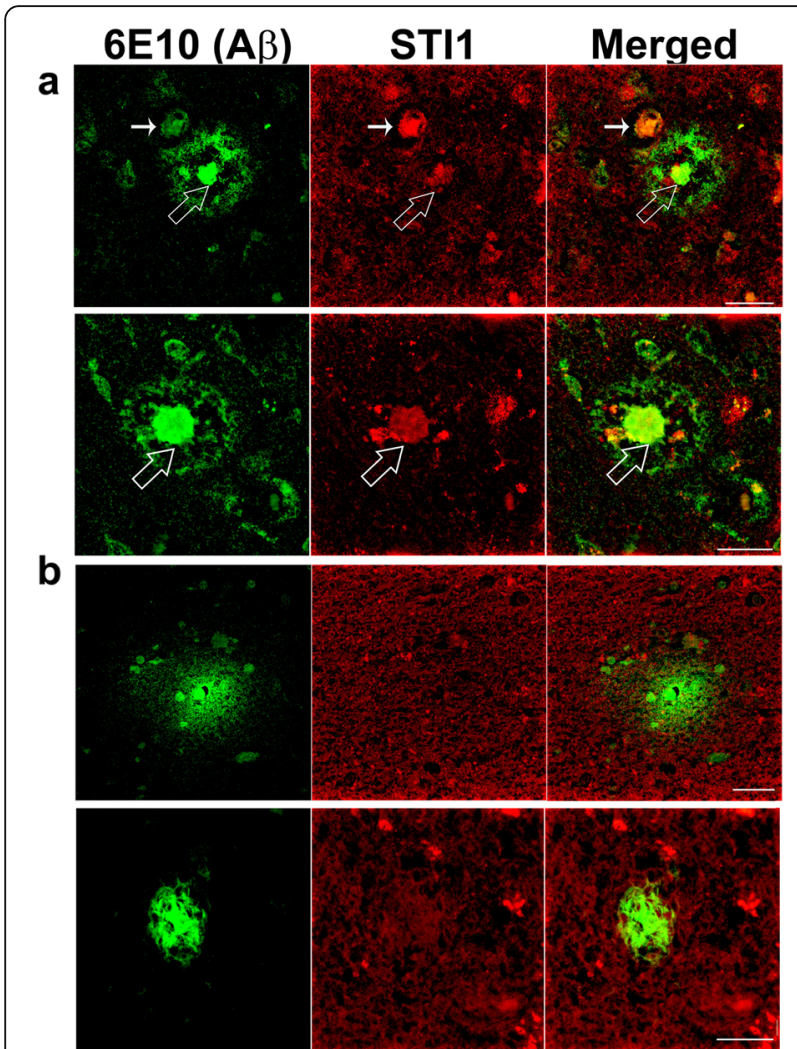

Fig. 8 Dense-core plaques in human Alzheimer's patients have extracellular STI1 deposits. a Representative images of mature dense core $A \beta$ plaques (63X) from five $A D$ patients in temporal and parietal cortex. $\mathbf{b}$ Representative images of diffuse $A \beta$ plaques images from five $A D$ patients (63X). Green is for $A \beta$ (anti-6E10), red for STI1. Scale bars $=25 \mu \mathrm{m}$. Large white arrowhead show STI1 and $A \beta$ colocalization, small filled white arrowheads show STI1 $+A \beta$ immunoreactive blood vessels

resulted in much more complex effects in vivo. In general, we show that increasing STI1 and Hsp90 levels in mice overexpressing human APP with mutations that favour the generation of toxic $A \beta$ peptides ( $5 x F A D)$, escalated the accumulation of insoluble protein aggregates. Importantly, measures of cellular toxicity in brain tissue, and mouse behavioral tests suggest that increased insoluble $A \beta$ plaque burden are linked to worse outcome in TgA-5xFAD mice. However, given the resulting increase of Hsp90 due to overexpression of STI1, it remains unknown if overexpression of Hsp90 $\beta$ alone in 5xFAD mice would lead to the same increase in amyloid burden or impact levels of STI1 in vivo. In vitro neuronal assays with recombinant Hsp90 and STI1 by Maciejewski et al. [48] revealed that surplus addition of Hsp90 in the presence of increasing concentrations of STI1 prevented STI1 neuroprotection against $\mathrm{A} \beta \mathrm{O}$. These results suggest that excessive levels of Hsp90 interferes with STI1 binding to $\operatorname{PrP}^{\mathrm{C}}$, which could explain why more neurodegeneration was found in TgA-5xFAD mice.
Different types of $A \beta$ aggregates may act in different ways to affect neurons. Numerous recent experiments have focused on the toxicity of $A \beta$ oligomers and demonstrated that these toxic species interact with the prion protein to trigger maladaptive neuronal signalling [19, 29, 93-95]. In vitro data suggest that extracellular STI1 is beneficial for neurons either by leading to increased protein translation [96], neuritogenesis [26], or protecting neurons against a number of chemical or environmental insults $[25,26,28]$. Indeed, we found that secreted STI1 by TgA neurons was responsible for the enhanced resilience against $A \beta O$, since blocking STI1 with an anti-STI1 antibody abolished this protection.

In addition to the toxic effects of $A \beta O$ s, the accumulation of insoluble forms of $\mathrm{A} \beta$ can trigger ER stress [54, 97-99] and burden cellular protein quality control. Interestingly, transcriptomic analyses of $\mathrm{AD}$ patients' brains identified STI1 as a regulator of the unfolded protein response [31]. In yeast, which have highly conserved STI1 and Hsp90 genes, STI1 activity seems to be vulnerable to excessive amounts of accumulated exogenous proteins [42], which then disturbs chaperone network activity. Moreover, increased levels of STI1 decreased amyloid toxicity in yeast, by regulating their spatial distribution and toxic assembly [35]. These results suggest that increasing the levels of STI1 and Hsp90 seem to help certain organisms, such as yeast and worms, whose $\mathrm{A} \beta$ is not secreted and remains intracellularly $[35,100]$ to deal with the increased proteotoxicity of amyloid proteins. Although our results in C. elegans, an organism that does not have a homologue for the prion protein, are in line with the in vitro experiments [29, 101], it is clear that in mice the extracellular effects of STI1 via the prion protein do not seem to be as relevant as other actions, such as STI1 modulation of proteostasis and protein aggregation.

STI1 and Hsp90 are secreted by a myriad of cells and have the potential to be found extracellularly in the mammalian brain $[25,85-87,102]$. Regulation of extracellular Hsp90 by co-chaperones, and extracellular Hsp90 chaperone activity is not well studied, but it was recently found that extracellular Hsp90 is regulated by co-chaperones Aha1 and TIMP2 to regulate their client protein MMP-2 [103]. These results raise the possibility that extracellular STI1 could indeed be regulating and altering the Hsp70/Hsp90 machinery. Moreover, the increased levels of STI1 and consequent increase in Hsp90 appear to contribute to augmented $A \beta$ burden in mice in different ways. The levels of BACE1 were increased three-fold, whereas MMP-2, an important enzyme for amyloid $\beta$ degradation, and an Hsp90 client, was significantly decreased. However, APP levels were not different between 5xFAD and TgA-5xFAD mice. We detected no evidence that microglia close to plaques were altered, 
suggesting that increased STI1 levels may not affect this mechanism of plaque removal.

There has been debate in the literature as to whether amyloid plaques are indeed toxic or may be a means to protect cells against $A \beta$-peptide and $A \beta O$ toxicity [61, $62,104,105]$. Our results show that the amplified amyloid burden in TgA-5xFAD correlates with increased neurodegeneration, post-synaptic density loss, increased apoptosis, as well as worse performance of mice in the spatial MWM. Hence, it seems that at least for the $5 x F A D$ mouse line, the increase in plaques was not protective and $A \beta$ oligomer toxicity does not play a major role in the toxicity, given that this should be blocked by extracellular STI1.

The role of Hsp70/Hsp90 and STI1 in other types of protein misfolding diseases is starting to be investigated and warrants further analysis. Tau is a client of Hsp90 and inhibition of Hsp90 to stimulate Hsp90 re-folding pathway seems to favour degradation of overexpressed misfolded tau and phosphotau [106]. Hsp90 co-chaperones STI1, Hsp40, CHIP, p23, and Pin1 were all necessary for mediating tau re-folding and/or degradation. Furthermore, STI1/ Hop loss of function in Drosophila overexpressing the full-length $2 \mathrm{~N} / 4 \mathrm{R}$ isoform of wild-type human tau in the eye, resulted in significant loss of retinal cells [107]. Recently, Inda et al. [40] demonstrated that in $\mathrm{AD}$, chaperones associate to form large stable complexes, termed epichaperomes, that no longer regulate client protein function. These epichaperomes impaired protein connectivity, proteostasis, and synaptic plasticity in their AD mouse models [40], which could be corrected by disassembly of epichaperomes by an Hsp90 inhibitor. Since Hsp90, Hsp70 and STI1 are all members of these epichaperomes in AD tissues, it may be important to test in the future how increased or decreased levels of STI1 regulate epichaperomes.

Hsp90, along with other small Hsps have been previously found to co-localize with $A \beta$ plaques $[80,108-$ $111]$, however it is not fully elucidated whether this is a result from cellular debris or if the plaques sequester chaperones. We found STI1 and Hsp90 immunolabelling in dense core and neuritic plaques - the type of plaques that are associated with late stage $\mathrm{AD}$ and are typically surrounded by glial cells [112]. Interestingly, we similarly found that in AD patients, STI1 accumulates only within the dense core of senile plaques. Deposits of chaperones in protein aggregates may disturb chaperone function, suggesting that molecular chaperone activity may be impaired in $\mathrm{AD}$, potentially affecting a number of client proteins.

In summary we found a striking difference between the actions of Hsp90 and STI1 in C. elegans and in mice.
Overall, the observations presented here suggest a complex relationship between Hsp90, STI1, and A $\beta$ peptides in mammals. These results support the notion that increased STI1 levels found in human AD patient brain tissue [29], may contribute to amyloidogenesis and paradoxically increase toxicity in vivo.

\begin{abstract}
Acknowledgements
Marco A. M Prado and Vania F. Prado received support from the Canadian Institutes of Health Research (PJT 162431, PJT 159781, MOP 136930, MOP 89919), National Science and Engineering Research Council of Canada (402524-2013 RGPIN), ALS Society, BrainsCAN Accelerator Grant scheme and the Alzheimer's Society of Canada. Behavioural testing is supported by BrainsCAN, a Canada First Research Excellence Grant for The University of Western Ontario. Initial generation of STI1 mutant mice was supported by PrioNet-Canada and FAPESP (Brazil) to Marco A.M. Prado and Vania F. Prado. Marco A.M. Prado is a Tier I Canada Research Chair in Neurochemistry of Dementia. Rachel Lackie received support from OGS and the Alzheimer's Society of Canada through the Alzheimer's Society Research Program. Sarah Good was supported by Biotechnology and Biological Sciences Research Council (UK; BB/M011151/1) The funding agencies did not have any role in experimental design, data collection and analysis, decision to publish, or preparation of the manuscript.
\end{abstract}

\section{Research involving human participants, their data or biological material}

Human post-mortem brain tissue was obtained with informed consent and approval from Office of Research Ethics Protocol 162656E of the University of Western Ontario.

\section{Authors' contributions}

REL collected tissue, performed histological processing and immunostaining, biochemistry, Western blotting, ELISA, designed experiments, analyzed data, prepared figures, figure legends, and wrote the manuscript. JML collected tissue, performed histological experiments, performed behavioural studies, analyzed data, prepared early figure versions, edited the manuscript. SG generated C. elegans strains, performed C. elegans experiments, analyzed data, wrote manuscript. VGO performed experiments and edited the manuscript. W-YC edited the manuscript. PVOH designed C. elegans experiments, wrote the manuscript. SP provided post-mortem human brain tissue and edited the manuscript. VFP directed research, designed experiments, edited manuscript. MAMP designed experiments, directed research and wrote the manuscript. The author(s) read and approved the final manuscript.

\section{Availability of data and materials}

Datasets were deposited in Figshare, and are publicly available. Figure 1: https://doi.org/10.6084/m9.figshare.12115614 Figure 2: https://doi.org/10. 6084/m9.figshare.12115704 Figure 3: https://doi.org/10.6084/m9.figshare. 12115713 Figure 4: https://doi.org/10.6084/m9.figshare.12115716 Figure 5: https://doi.org/10.6084/m9.figshare.12115758 Figure 6: https://doi.org/10. 6084/m9.figshare.12115758.

\section{Competing interests}

The authors declare no conflicts of interest.

\section{Author details}

${ }^{1}$ Robarts Research Institute, The University of Western Ontario, 1151 Richmond St. N., London, Ontario N6A 5B7, Canada. ${ }^{2}$ Program in Neuroscience, The University of Western Ontario, 1151 Richmond St, London N6A 3K7, Canada. ${ }^{3}$ School of Molecular and Cell Biology and Astbury Centre for Structural Molecular Biology, University of Leeds, Leeds LS2 9JT, UK. ${ }^{4}$ Department of Biochemistry, Schulich School of Medicine \& Dentistry, The University of Western Ontario, Medical Sciences Building, 1151 Richmond St. N, London N6A 5B7, Canada. ${ }^{5}$ St. Joseph's Health Care London-Parkwood Institute, St. Joseph's Hospital, 268 Grosvenor St Room A1-015, London N6A 4V2, Canada. ${ }^{6}$ Department of Clinical Neurological Sciences, Schulich School of Medicine \& Dentistry, 1151 Richmond St, London N6A 3K7, Canada. ${ }^{7}$ Department of Anatomy \& Cell Biology, The University of Western Ontario, 1151 Richmond St, London N6A 3K7, Canada. ${ }^{8}$ Department of Physiology and Pharmacology, Schulich School of Medicine and Dentistry, The 
University of Western Ontario, 1151 Richmond St, London N6A 3K7, Ontario Canada.

\section{Received: 29 July 2020 Accepted: 1 August 2020}

Published online: 21 August 2020

\section{References}

1. Collaborators GBDD (2019) Global, regional, and national burden of Alzheimer's disease and other dementias, 1990-2016: a systematic analysis for the global burden of disease study 2016. The Lancet Neurology 18:88106. https://doi.org/10.1016/S1474-4422(18)30403-4

2. O'Brien RJ, Wong PC (2011) Amyloid precursor protein processing and Alzheimer's disease. Annu Rev Neurosci 34:185-204. https://doi.org/10.1146/ annurev-neuro-061010-113613

3. Thinakaran G, Koo EH (2008) Amyloid precursor protein trafficking processing, and function. J Biol Chem 283:29615-29619. doi:10.1074/jbc. R800019200

4. Ueda K, Fukushima H, Masliah E, Xia Y, Iwai A, Yoshimoto M, Otero DA, Kondo J, Ihara Y, Saitoh T (1993) Molecular cloning of CDNA encoding an unrecognized component of amyloid in Alzheimer disease. Proc Natl Acad Sci U S A 90:11282-11286

5. Weidemann A, Konig G, Bunke D, Fischer P, Salbaum JM, Masters $C L$, Beyreuther K (1989) Identification, biogenesis, and localization of precursors of Alzheimer's disease A4 amyloid protein. Cell 57:115-126

6. Bieschke J, Herbst M, Wiglenda T, Friedrich RP, Boeddrich A, Schiele F, Kleckers D, Lopez del Amo JM, Gruning BA, Wang Q, Schmidt MR, Lurz R, Anwyl R, Schnoegl S, Fandrich M, Frank RF, Reif B, Gunther S, Walsh DM, Wanker EE (2011) Small-molecule conversion of toxic oligomers to nontoxic beta-sheet-rich amyloid fibrils. Nat Chem Biol 8:93-101. https://doi.org/10. 1038/nchembio.719

7. Cleary JP, Walsh DM, Hofmeister JJ, Shankar GM, Kuskowski MA, Selkoe DJ, Ashe KH (2005) Natural oligomers of the amyloid-beta protein specifically disrupt cognitive function. Nat Neurosci 8:79-84. https://doi.org/10.1038/ nn1372

8. Ferreira ST, Klein WL (2011) The Abeta oligomer hypothesis for synapse failure and memory loss in Alzheimer's disease. Neurobiol Learn Mem 96: 529-543. https://doi.org/10.1016/j.nlm.2011.08.003

9. Fowler SW, Chiang AC, Savjani RR, Larson ME, Sherman MA, Schuler DR, Cirrito JR, Lesne SE, Jankowsky JL (2014) Genetic modulation of soluble Abeta rescues cognitive and synaptic impairment in a mouse model of Alzheimer's disease. J Neurosci 34:7871-7885. https://doi.org/10.1523/ JNEUROSCI.0572-14.2014

10. Klein WL (2002) ADDLs \& protofibrils--the missing links? Neurobiol Aging 23: 231-235

11. Klein WL, Krafft GA, Finch CE (2001) Targeting small Abeta oligomers: the solution to an Alzheimer's disease conundrum? Trends Neurosci 24:219-224

12. Lambert MP, Barlow AK, Chromy BA, Edwards C, Freed R, Liosatos M, Morgan TE, Rozovsky I, Trommer B, Viola KL, Wals P, Zhang C, Finch CE, Krafft GA, Klein WL (1998) Diffusible, nonfibrillar ligands derived from Abeta1-42 are potent central nervous system neurotoxins. Proc Natl Acad Sci U S A 95:6448-6453

13. Walsh DM, Klyubin I, Fadeeva JV, Cullen WK, Anwyl R, Wolfe MS, Rowan MJ, Selkoe DJ (2002) Naturally secreted oligomers of amyloid beta protein potently inhibit hippocampal long-term potentiation in vivo. Nature 416: 535-539. https://doi.org/10.1038/416535a

14. Wang HW, Pasternak JF, Kuo H, Ristic H, Lambert MP, Chromy B, Viola KL, Klein WL, Stine WB, Krafft GA, Trommer BL (2002) Soluble oligomers of beta amyloid (1-42) inhibit long-term potentiation but not long-term depression in rat dentate gyrus. Brain Res 924:133-140. https://doi.org/10.1016/s00068993(01)03058-x

15. Hardy J, Selkoe DJ (2002) The amyloid hypothesis of Alzheimer's disease: progress and problems on the road to therapeutics. Science 297:353-356. https://doi.org/10.1126/science.1072994

16. Selkoe DJ, Hardy J (2016) The amyloid hypothesis of Alzheimer's disease at 25 years. EMBO Mol med 8:595-608. Doi:10.15252/emmm.201606210

17. Beraldo FH, Ostapchenko VG, Caetano FA, Guimaraes AL, Ferretti GD, Daude N, Bertram L, Nogueira KO, Silva JL, Westaway D, Cashman NR, Martins VR, Prado VF, Prado MA (2016) Regulation of amyloid beta oligomer binding to neurons and neurotoxicity by the prion protein-mGluR5 complex. J Biol Chem 291:21945-21955. doi:10.1074/jbc. M116.738286
18. Gunther EC, Strittmatter SM (2010) Beta-amyloid oligomers and cellular prion protein in Alzheimer's disease. J Mol Med (Berl) 88:331-338. https:// doi.org/10.1007/s00109-009-0568-7

19. Lauren J, Gimbel DA, Nygaard HB, Gilbert JW, Strittmatter SM (2009) Cellular prion protein mediates impairment of synaptic plasticity by amyloid-beta oligomers. Nature 457:1128-1132. https://doi.org/10.1038/nature07761

20. Reiniger L, Lukic A, Linehan J, Rudge P, Collinge J, Mead S, Brandner S (2011) Tau, prions and Abeta: the triad of neurodegeneration. Acta Neuropathol 121:5-20. https://doi.org/10.1007/s00401-010-0691-0

21. Linden $R$ (2017) The biological function of the prion protein: a cell surface scaffold of signaling modules. Front Mol Neurosci 10:77. https://doi.org/10. 3389/fnmol.2017.00077

22. Linden R, Martins VR, Prado MA, Cammarota M, Izquierdo I, Brentani RR (2008) Physiology of the prion protein. Physiol Rev 88:673-728. https://doi. org/10.1152/physrev.00007.2007

23. Martins VR, Beraldo FH, Hajj GN, Lopes MH, Lee KS, Prado MA, Linden R (2010) Prion protein: orchestrating neurotrophic activities. Curr Issues Mol Biol 12:63-86

24. Beraldo FH, Arantes CP, Santos TG, Queiroz NG, Young K, Rylett RJ, Markus RP, Prado MA, Martins VR (2010) Role of alpha7 nicotinic acetylcholine receptor in calcium signaling induced by prion protein interaction with stress-inducible protein 1. J Biol Chem 285:36542-36550. doi:10.1074/jbc. M110.157263

25. Beraldo FH, Soares IN, Goncalves DF, Fan J, Thomas AA, Santos TG, Mohammad AH, Roffe M, Calder MD, Nikolova S, Hajj GN, Guimaraes AL, Massensini AR, Welch I, Betts DH, Gros R, Drangova M, Watson AJ, Bartha R, Prado VF, Martins VR, Prado MA (2013) Stress-inducible phosphoprotein 1 has unique cochaperone activity during development and regulates cellular response to ischemia via the prion protein. FASEB J 27:3594-3607. https:// doi.org/10.1096/fj.13-232280

26. Lopes MH, Hajj GN, Muras AG, Mancini GL, Castro RM, Ribeiro KC, Brentani RR, Linden R, Martins VR (2005) Interaction of cellular prion and stressinducible protein 1 promotes neuritogenesis and neuroprotection by distinct signaling pathways. J Neurosci 25:11330-11339. https://doi.org/10. 1523/JNEUROSCI.2313-05.2005

27. Santos TG, Silva IR, Costa-Silva B, Lepique AP, Martins VR, Lopes MH (2011) Enhanced neural progenitor/stem cells self-renewal via the interaction of stress-inducible protein 1 with the prion protein. Stem Cells 29:1126-1136. https://doi.org/10.1002/stem.664

28. Zanata SM, Lopes MH, Mercadante AF, Hajj GN, Chiarini LB, Nomizo R, Freitas AR, Cabral AL, Lee KS, Juliano MA, de Oliveira E, Jachieri SG, Burlingame A, Huang L, Linden R, Brentani RR, Martins VR (2002) Stressinducible protein 1 is a cell surface ligand for cellular prion that triggers neuroprotection. EMBO J 21:3307-3316. https://doi.org/10.1093/emboj/ cdf325

29. Ostapchenko VG, Beraldo FH, Mohammad AH, Xie YF, Hirata PH, Magalhaes AC, Lamour G, Li H, Maciejewski A, Belrose JC, Teixeira BL, Fahnestock M, Ferreira ST, Cashman NR, Hajj GN, Jackson MF, Choy WY, MacDonald JF, Martins VR, Prado VF, Prado MA (2013) The prion protein ligand, stressinducible phosphoprotein 1, regulates amyloid-beta oligomer toxicity. J Neurosci 33:16552-16564. https://doi.org/10.1523/JNEUROSCI.3214-13.2013

30. Brehme M, Voisine C, Rolland T, Wachi S, Soper JH, Zhu Y, Orton K, Villella A, Garza D, Vidal M, Ge H, Morimoto RI (2014) A chaperome subnetwork safeguards proteostasis in aging and neurodegenerative disease. Cell Rep 9: 1135-1150. https://doi.org/10.1016/..celrep.2014.09.042

31. Zhang B, Gaiteri C, Bodea LG, Wang Z, McElwee J, Podtelezhnikov AA, Zhang C, Xie T, Tran L, Dobrin R, Fluder E, Clurman B, Melquist S, Narayanan M, Suver C, Shah H, Mahajan M, Gillis T, Mysore J, MacDonald ME, Lamb JR, Bennett DA, Molony C, Stone DJ, Gudnason V, Myers AJ, Schadt EE, Neumann H, Zhu J, Emilsson V (2013) Integrated systems approach identifies genetic nodes and networks in late-onset Alzheimer's disease. Cell 153:707-720. https://doi.org/10.1016/.cell.2013.03.030

32. Lackie RE, Razzaq AR, Farhan SMK, Qiu LR, Moshitzky G, Beraldo FH, Lopes MH, Maciejewski A, Gros R, Fan J, Choy WY, Greenberg DS, Martins VR, Duennwald ML, Lerch JP, Soreq H, Prado VF, Prado MAM (2020) Modulation of hippocampal neuronal resilience during aging by the Hsp70/Hsp90 cochaperone STI1. J Neurochem 153(6):727-758. https://doi.org/10.1111/jnc. 14882.

33. Lee CT, Graf C, Mayer FJ, Richter SM, Mayer MP (2012) Dynamics of the regulation of Hsp90 by the co-chaperone Sti1. EMBO J 31:1518-1528. https://doi.org/10.1038/emboj.2012.37 
34. Rohl A, Tippel F, Bender E, Schmid AB, Richter K, Madl T, Buchner J (2015) Hop/Sti1 phosphorylation inhibits its co-chaperone function. EMBO rep 16 240-249. Doi:10.15252/embr.201439198

35. Wolfe KJ, Ren HY, Trepte P, Cyr DM (2013) The Hsp70/90 cochaperone, Sti1, suppresses proteotoxicity by regulating spatial quality control of amyloidlike proteins. Mol Biol Cell 24:3588-3602. doi:10.1091/mbc. E13-06-0315

36. Bukau B, Weissman J, Horwich A (2006) Molecular chaperones and protein quality control. Cell 125:443-451. https://doi.org/10.1016/j.cell.2006.04.014

37. Csermely P, Schnaider T, Soti C, Prohaszka Z, Nardai G (1998) The 90-kDa molecular chaperone family: structure, function, and clinical applications. A comprehensive review. Pharmacol Ther 79:129-168

38. Lackie RE, Maciejewski A, Ostapchenko VG, Marques-Lopes J, Choy WY, Duennwald ML, Prado VF, Prado MAM (2017) The Hsp70/Hsp90 chaperone machinery in neurodegenerative diseases. Front Neurosci 11:254. https://doi. org/10.3389/fnins.2017.00254

39. Pratt WB, Gestwicki JE, Osawa Y, Lieberman AP (2015) Targeting Hsp90/ Hsp70-based protein quality control for treatment of adult onset neurodegenerative diseases. Annu Rev Pharmacol Toxicol 55:353-371. https://doi.org/10.1146/annurev-pharmtox-010814-124332

40. Inda MC, Joshi S, Wang T, Bolaender A, Gandu S, Koren lii J, Che AY, Taldone T, Yan P, Sun W, Uddin M, Panchal P, Riolo M, Shah S, Barlas A, Xu K, Chan LYL, Gruzinova A, Kishinevsky S, Studer L, Fossati V, Noggle SA, White JR, de Stanchina E, Sequeira S, Anthoney KH, Steele JW, ManovaTodorova K, Patil S, Dunphy MP, Pillarsetty N, Pereira AC, ErdjumentBromage H, Neubert TA, Rodina A, Ginsberg SD, De Marco GN, Luo W, Chiosis G (2020) The epichaperome is a mediator of toxic hippocampal stress and leads to protein connectivity-based dysfunction. Nat Commun 11:319. https://doi.org/10.1038/s41467-019-14082-5

41. Wang B, Liu Y, Huang L, Chen J, Li JJ, Wang R, Kim E, Chen Y, Justicia C, Sakata K, Chen H, Planas A, Ostrom RS, Li W, Yang G, McDonald MP, Chen R, Heck DH, Liao FF (2016) A CNS-permeable Hsp90 inhibitor rescues synaptic dysfunction and memory loss in APP-overexpressing Alzheimer's mouse model via an HSF1-mediated mechanism. Mol Psychiatry. https://doi.org/10. 1038/mp.2016.104

42. Farkas Z, Kalapis D, Bodi Z, Szamecz B, Daraba A, Almasi K, Kovacs K, Boross G, Pal F, Horvath P, Balassa T, Molnar C, Pettko-Szandtner A, Klement E, Rutkai E, Szvetnik A, Papp B, Pal C (2018) Hsp70-associated chaperones have a critical role in buffering protein production costs. Elife 7. https://doi.org/ 10.7554/eLife.29845

43. Reidy M, Masison DC (2010) Sti1 regulation of Hsp70 and Hsp90 is critical for curing of Saccharomyces cerevisiae [PSI+] prions by Hsp104. Mol Cell Biol 30:3542-3552. https://doi.org/10.1128/MCB.01292-09

44. Song HO, Lee W, An K, Lee HS, Cho JH, Park ZY, Ahnn J (2009) C. elegans STI-1, the homolog of Sti1/hop, is involved in aging and stress response. J Mol Biol 390:604-617. https://doi.org/10.1016/j.jmb.2009.05.035

45. Beraldo FH, Ostapchenko VG, Xu JZ, Di Guglielmo GM, Fan J, Nicholls PJ, Caron MG, Prado VF, Prado MAM (2018) Mechanisms of neuroprotection against ischemic insult by stress-inducible phosphoprotein-1/prion protein complex. J Neurochem 145:68-79. https://doi.org/10.1111/jnc.14281

46. Brenner S (1974) The genetics of Caenorhabditis elegans. Genetics 77:71-94

47. van Oosten-Hawle P, Porter RS, Morimoto RI (2013) Regulation of organismal proteostasis by transcellular chaperone signaling. Cell 153:13661378. https://doi.org/10.1016/j.cell.2013.05.015

48. Maciejewski A, Ostapchenko VG, Beraldo FH, Prado VF, Prado MA, Choy WY (2016) Domains of STIP1 responsible for regulating PrPC-dependent amyloid-beta oligomer toxicity. Biochem J 473:2119-2130. https://doi.org/ 10.1042/BCJ20160087

49. Beraldo FH, Thomas A, Kolisnyk B, Hirata PH, De Jaeger X, Martyn AC, Fan J, Goncalves DF, Cowan MF, Masood T, Martins VR, Gros R, Prado VF, Prado MA (2015) Hyperactivity and attention deficits in mice with decreased levels of stress-inducible phosphoprotein 1 (STIP1). Dis Model Mech 8:1457-1466. https://doi.org/10.1242/dmm.022525

50. Kolisnyk B, Al-Onaizi M, Soreq L, Barbash S, Bekenstein U, Haberman N, Hanin G, Kish MT, Souza da Silva J, Fahnestock M, Ule J, Soreq H, Prado VF, Prado MAM (2017) Cholinergic surveillance over hippocampal RNA metabolism and Alzheimer's-like pathology. Cereb Cortex 27:3553-3567. https://doi.org/10.1093/cercor/bhw177

51. Kolisnyk B, Guzman MS, Raulic S, Fan J, Magalhaes AC, Feng G, Gros R, Prado VF, Prado MA (2013) ChAT-ChR2-EYFP mice have enhanced motor endurance but show deficits in attention and several additional cognitive domains. J Neurosci 33:10427-10438. https://doi.org/10.1523/JNEUROSCI. 0395-13.2013

52. Tang $X$, Wu D, Gu LH, Nie BB, Qi XY, Wang YJ, Wu FF, Li XL, Bai F, Chen XC, Xu L, Ren QG, Zhang ZJ (2016) Spatial learning and memory impairments are associated with increased neuronal activity in 5XFAD mouse as measured by manganese-enhanced magnetic resonance imaging. Oncotarget 7:57556-57570. Doi:10.18632/oncotarget.11353

53. Guzman MS, De Jaeger X, Raulic S, Souza IA, Li AX, Schmid S, Menon RS, Gainetdinov RR, Caron MG, Bartha R, Prado VF, Prado MA (2011) Elimination of the vesicular acetylcholine transporter in the striatum reveals regulation of behaviour by cholinergic-glutamatergic co-transmission. PLoS Biol 9: e1001194. https://doi.org/10.1371/journal.pbio.1001194

54. Ostapchenko VG, Chen M, Guzman MS, Xie YF, Lavine N, Fan J, Beraldo FH, Martyn AC, Belrose JC, Mori Y, MacDonald JF, Prado VF, Prado MA, Jackson MF (2015) The transient receptor potential Melastatin 2 (TRPM2) channe contributes to beta-amyloid oligomer-related neurotoxicity and memory impairment. J Neurosci 35:15157-15169. https://doi.org/10.1523/JNEUROSCI. 4081-14.2015

55. Beraldo FH, Palmer D, Memar S, Wasserman DI, Lee WV, Liang S, Creighton SD, Kolisnyk B, Cowan MF, Mels J, Masood TS, Fodor C, Al-Onaizi MA, Bartha R, Gee T, Saksida LM, Bussey TJ, Strother SS, Prado VF, Winters BD, Prado MA (2019) MouseBytes, an open-access high-throughput pipeline and database for rodent touchscreen-based cognitive assessment. Elife 8. https://doi.org/ 10.7554/eLife.49630

56. Evans CG, Wisen S, Gestwicki JE (2006) Heat shock proteins 70 and 90 inhibit early stages of amyloid beta-(1-42) aggregation in vitro. J Biol Chem 281:33182-33191. doi:10.1074/jbc. M606192200

57. Chang HC, Nathan DF, Lindquist S (1997) In vivo analysis of the Hsp90 cochaperone Sti1 (p60). Mol Cell Biol 17:318-325

58. Yakupova El, Bobyleva LG, Vikhlyantsev IM, Bobylev AG (2019) Congo Red and amyloids: history and relationship Biosci Rep:39. https://doi.org/10.1042/ BSR20181415

59. Bussiere T, Bard F, Barbour R, Grajeda H, Guido T, Khan K, Schenk D, Games D, Seubert P, Buttini M (2004) Morphological characterization of ThioflavinS-positive amyloid plaques in transgenic Alzheimer mice and effect of passive Abeta immunotherapy on their clearance. Am J Pathol 165:987-995. https://doi.org/10.1016/s0002-9440(10)63360-3

60. Oakley H, Cole SL, Logan S, Maus E, Shao P, Craft J, Guillozet-Bongaarts A, Ohno M, Disterhoft J, Van Eldik L, Berry R, Vassar R (2006) Intraneuronal beta-amyloid aggregates, neurodegeneration, and neuron loss in transgenic mice with five familial Alzheimer's disease mutations: potential factors in amyloid plaque formation. J Neurosci 26:10129-10140. https://doi.org/10. 1523/JNEUROSCI.1202-06.2006

61. Esparza TJ, Gangolli M, Cairns NJ, Brody DL (2018) Soluble amyloid-beta buffering by plaques in Alzheimer disease dementia versus high-pathology controls. PLoS One 13:e0200251. https://doi.org/10.1371/journal.pone. 0200251

62. Treusch S, Cyr DM, Lindquist S (2009) Amyloid deposits: protection against toxic protein species? Cell Cycle 8:1668-1674. https://doi.org/10.4161/cc.8. 11.8503

63. Cheng WH, Stukas S, Martens KM, Namjoshi DR, Button EB, Wilkinson A, Bashir A, Robert J, Cripton PA, Wellington CL (2018) Age at injury and genotype modify acute inflammatory and neurofilament-light responses to mild CHIMERA traumatic brain injury in wild-type and APP/PS1 mice. Exp Neurol 301:26-38. https://doi.org/10.1016/j.expneurol.2017.12.007

64. Javidnia M, Hebron ML, Xin Y, Kinney NG, Moussa CE (2017) Pazopanib reduces phosphorylated tau levels and alters astrocytes in a mouse model of Tauopathy. J Alzheimers Dis 60:461-481. https://doi.org/10.3233/JAD170429

65. Krstic D, Madhusudan A, Doehner J, Vogel P, Notter T, Imhof C, Manalastas A, Hilfiker M, Pfister S, Schwerdel C, Riether C, Meyer U, Knuesel I (2012) Systemic immune challenges trigger and drive Alzheimer-like neuropathology in mice. J Neuroinflammation 9:151. https://doi.org/10. 1186/1742-2094-9-151

66. Yoon SO, Park DJ, Ryu JC, Ozer HG, Tep C, Shin YJ, Lim TH, Pastorino L, Kunwar AJ, Walton JC, Nagahara AH, Lu KP, Nelson RJ, Tuszynski MH, Huang K (2012) JNK3 perpetuates metabolic stress induced by Abeta peptides. Neuron 75:824-837. https://doi.org/10.1016/j.neuron.2012.06.024

67. Shao CY, Mirra SS, Sait HB, Sacktor TC, Sigurdsson EM (2011) Postsynaptic degeneration as revealed by PSD-95 reduction occurs after advanced Abeta 
and tau pathology in transgenic mouse models of Alzheimer's disease. Acta Neuropathol 122:285-292. https://doi.org/10.1007/s00401-011-0843-x

68. Schneider F, Baldauf K, Wetzel W, Reymann KG (2014) Behavioral and EEG changes in male 5xFAD mice. Physiol Behav 135:25-33. https://doi.org/10. 1016/j.physbeh.2014.05.041

69. Cole SL, Vassar R (2008) The role of amyloid precursor protein processing by BACE1, the beta-secretase, in Alzheimer disease pathophysiology. J Biol Chem 283:29621-29625. doi:10.1074/jbc. R800015200

70. Luo Y, Bolon B, Kahn S, Bennett BD, Babu-Khan S, Denis P, Fan W, Kha H, Zhang J, Gong Y, Martin L, Louis JC, Yan Q, Richards WG, Citron M, Vassar R (2001) Mice deficient in BACE1, the Alzheimer's beta-secretase, have normal phenotype and abolished beta-amyloid generation. Nat Neurosci 4:231-232. https://doi.org/10.1038/85059

71. Vassar R, Bennett BD, Babu-Khan S, Kahn S, Mendiaz EA, Denis P, Teplow DB, Ross S, Amarante P, Loeloff R, Luo Y, Fisher S, Fuller J, Edenson S, Lile J, Jarosinski MA, Biere AL, Curran E, Burgess T, Louis JC, Collins F, Treanor J, Rogers G, Citron M (1999) Beta-secretase cleavage of Alzheimer's amyloid precursor protein by the transmembrane aspartic protease BACE. Science 286:735-741. https://doi.org/10.1126/science.286.5440.735

72. Sims JD, McCready J, Jay DG (2011) Extracellular heat shock protein (Hsp)70 and Hsp90alpha assist in matrix metalloproteinase-2 activation and breast cancer cell migration and invasion. PLoS One 6:e18848. https://doi.org/10. 1371/journal.pone.0018848

73. Walsh N, Larkin A, Swan N, Conlon K, Dowling P, McDermott R, Clynes M (2011) RNAi knockdown of hop (Hsp70/Hsp90 organising protein) decreases invasion via MMP-2 down regulation. Cancer Lett 306:180-189. https://doi. org/10.1016/j.canlet.2011.03.004

74. Py NA, Bonnet AE, Bernard A, Marchalant $\mathrm{Y}$, Charrat E, Checler F, Khrestchatisky M, Baranger K, Rivera S (2014) Differential spatio-temporal regulation of MMPs in the 5xFAD mouse model of Alzheimer's disease: evidence for a pro-amyloidogenic role of MT1-MMP. Front Aging Neurosci 6:247. https://doi.org/10.3389/fnagi.2014.00247

75. Nalivaeva NN, Belyaev ND, Zhuravin IA, Turner AJ (2012) The Alzheimer's amyloid-degrading peptidase, neprilysin: can we control it? Int J Alzheimers Dis 2012:383796. https://doi.org/10.1155/2012/383796

76. Wang DS, Lipton RB, Katz MJ, Davies P, Buschke H, Kuslansky G, Verghese J, Younkin SG, Eckman C, Dickson DW (2005) Decreased neprilysin immunoreactivity in Alzheimer disease, but not in pathological aging. J Neuropathol Exp Neurol 64:378-385. https://doi.org/10.1093/jnen/64.5.378

77. de Tullio MB, Castelletto V, Hamley IW, Martino Adami PV, Morelli L, Castano EM (2013) Proteolytically inactive insulin-degrading enzyme inhibits amyloid formation yielding non-neurotoxic abeta peptide aggregates. PLoS One 8: e59113. https://doi.org/10.1371/journal.pone.0059113

78. Farris W, Mansourian S, Chang Y, Lindsley L, Eckman EA, Frosch MP, Eckman CB, Tanzi RE, Selkoe DJ, Guenette S (2003) Insulin-degrading enzyme regulates the levels of insulin, amyloid beta-protein, and the beta-amyloid precursor protein intracellular domain in vivo. Proc Natl Acad Sci U S A 100: 4162-4167. https://doi.org/10.1073/pnas.0230450100

79. Fleisher-Berkovich S, Filipovich-Rimon T, Ben-Shmuel S, Hulsmann C, Kummer MP, Heneka MT (2010) Distinct modulation of microglial amyloid beta phagocytosis and migration by neuropeptides (i). J Neuroinflammation 7:61. https://doi.org/10.1186/1742-2094-7-61

80. Kakimura J, Kitamura Y, Takata K, Umeki M, Suzuki S, Shibagaki K, Taniguch T, Nomura Y, Gebicke-Haerter PJ, Smith MA, Perry G, Shimohama S (2002) Microglial activation and amyloid-beta clearance induced by exogenous heat-shock proteins. FASEB J 16:601-603

81. Koenigsknecht-Talboo J, Landreth GE (2005) Microglial phagocytosis induced by fibrillar beta-amyloid and IgGs are differentially regulated by proinflammatory cytokines. J Neurosci 25:8240-8249. https://doi.org/10. 1523/JNEUROSCI.1808-05.2005

82. Pan XD, Zhu YG, Lin N, Zhang J, Ye QY, Huang HP, Chen XC (2011) Microglial phagocytosis induced by fibrillar beta-amyloid is attenuated by oligomeric beta-amyloid: implications for Alzheimer's disease. Mol Neurodegener 6:45. https://doi.org/10.1186/1750-1326-6-45

83. Wei Z, Chen XC, Song Y, Pan XD, Dai XM, Zhang J, Cui XL, Wu XL, Zhu YG (2016) Amyloid beta protein aggravates neuronal senescence and cognitive deficits in 5XFAD mouse model of Alzheimer's disease. Chin Med J 129: 1835-1844. https://doi.org/10.4103/0366-6999.186646

84. Zeisel A, Hochgerner H, Lonnerberg P, Johnsson A, Memic F, van der Zwan J, Haring M, Braun E, Borm LE, La Manno G, Codeluppi S, Furlan A, Lee K, Skene N, Harris KD, Hjerling-Leffler J, Arenas E, Ernfors P, Marklund U,
Linnarsson S (2018) Molecular architecture of the mouse nervous system. Cell 174(999-1014):e1022. https://doi.org/10.1016/j.cell.2018.06.021

85. Fonseca AC, Romao L, Amaral RF, Assad Kahn S, Lobo D, Martins S, Marcondes de Souza J, Moura-Neto V, Lima FR (2012) Microglial stress inducible protein 1 promotes proliferation and migration in human glioblastoma cells. Neuroscience 200:130-141. https://doi.org/10.1016/j. neuroscience.2011.10.025

86. Hajj GN, Arantes CP, Dias MV, Roffe M, Costa-Silva B, Lopes MH, PortoCarreiro I, Rabachini T, Lima FR, Beraldo FH, Prado MA, Linden R, Martins VR (2013) The unconventional secretion of stress-inducible protein 1 by a heterogeneous population of extracellular vesicles. Cell Mol Life Sci 70: 3211-3227. https://doi.org/10.1007/s00018-013-1328-y

87. Takeuchi T, Suzuki M, Fujikake N, Popiel HA, Kikuchi H, Futaki S, Wada K, Nagai $Y$ (2015) Intercellular chaperone transmission via exosomes contributes to maintenance of protein homeostasis at the organismal level. Proc Natl Acad Sci U S A 112:E2497-E2506. https://doi.org/10.1073/pnas. 1412651112

88. Wang TH, Chao A, Tsai CL, Chang CL, Chen SH, Lee YS, Chen JK, Lin YJ, Chang PY, Wang CJ, Chao AS, Chang SD, Chang TC, Lai CH, Wang HS (2010) Stress-induced phosphoprotein 1 as a secreted biomarker for human ovarian cancer promotes cancer cell proliferation. Mol Cell Proteomics 9: 1873-1884. doi:10.1074/mcp. M110.000802

89. Guzhova I, Kislyakova K, Moskaliova O, Fridlanskaya I, Tytell M, Cheetham M, Margulis B (2001) In vitro studies show that Hsp70 can be released by glia and that exogenous Hsp70 can enhance neuronal stress tolerance. Brain Res 914:66-73. https://doi.org/10.1016/s0006-8993(01)02774-3

90. Fernandez-Funez P, Sanchez-Garcia J, de Mena L, Zhang Y, Levites Y, Khare S, Golde TE, Rincon-Limas DE (2016) Holdase activity of secreted Hsp70 masks amyloid-beta42 neurotoxicity in Drosophila. Proc Natl Acad Sci U S A 113:E5212-E5221. https://doi.org/10.1073/pnas.1608045113

91. Rivera I, Capone R, Cauvi DM, Arispe N, De Maio A (2018) Modulation of Alzheimer's amyloid beta peptide oligomerization and toxicity by extracellular Hsp70. Cell Stress Chaperones 23:269-279. https://doi.org/10. 1007/s12192-017-0839-0

92. Schirmer C, Lepvrier E, Duchesne L, Decaux O, Thomas D, Delamarche C, Garnier C (2016) Hsp90 directly interacts, in vitro, with amyloid structures and modulates their assembly and disassembly. Biochim Biophys Acta 1860: 2598-2609. https://doi.org/10.1016/j.bbagen.2016.07.033

93. Kudo W, Lee HP, Zou WQ, Wang X, Perry G, Zhu X, Smith MA, Petersen RB, Lee HG (2012) Cellular prion protein is essential for oligomeric amyloidbeta-induced neuronal cell death. Hum Mol Genet 21:1138-1144. https:// doi.org/10.1093/hmg/ddr542

94. Um JW, Nygaard HB, Heiss JK, Kostylev MA, Stagi M, Vortmeyer A, Wisniewski T, Gunther EC, Strittmatter SM (2012) Alzheimer amyloid-beta oligomer bound to postsynaptic prion protein activates Fyn to impair neurons. Nat Neurosci 15:1227-1235. https://doi.org/10.1038/nn.3178

95. Um JW, Strittmatter SM (2013) Amyloid-beta induced signaling by cellular prion protein and Fyn kinase in Alzheimer disease. Prion 7:37-41. https:// doi.org/10.4161/pri.22212

96. Roffe M, Beraldo FH, Bester R, Nunziante M, Bach C, Mancini G, Gilch S, Vorberg I, Castilho BA, Martins VR, Hajj GN (2010) Prion protein interaction with stress-inducible protein 1 enhances neuronal protein synthesis via mTOR. Proc Natl Acad Sci U S A 107:13147-13152. https://doi.org/10.1073/ pnas.1000784107

97. Chafekar SM, Hoozemans JJ, Zwart R, Baas F, Scheper W (2007) Abeta 1-42 induces mild endoplasmic reticulum stress in an aggregation statedependent manner. Antioxid Redox Signal 9:2245-2254. https://doi.org/10. 1089/ars.2007.1797

98. Costa RO, Ferreiro E, Martins I, Santana I, Cardoso SM, Oliveira CR, Pereira CM (2012) Amyloid beta-induced ER stress is enhanced under mitochondrial dysfunction conditions. Neurobiol Aging 33(824):e825-e816. https://doi.org/10.1016/j.neurobiolaging.2011.04.011

99. Hoozemans JJ, van Haastert ES, Nijholt DA, Rozemuller AJ, Eikelenboom P, Scheper W (2009) The unfolded protein response is activated in pretangle neurons in Alzheimer's disease hippocampus. Am J Pathol 174:1241-1251. https://doi.org/10.2353/ajpath.2009.080814

100. Link CD, Johnson CJ, Fonte V, Paupard M, Hall DH, Styren S, Mathis CA, Klunk WE (2001) Visualization of fibrillar amyloid deposits in living, transgenic Caenorhabditis elegans animals using the sensitive amyloid dye, X-34. Neurobiol Aging 22:217-226. https://doi.org/10.1016/s0197$4580(00) 00237-2$ 
101. Ansar S, Burlison JA, Hadden MK, Yu XM, Desino KE, Bean J, Neckers L, Audus KL, Michaelis ML, Blagg BS (2007) A non-toxic Hsp90 inhibitor protects neurons from Abeta-induced toxicity. Bioorg Med Chem Lett 17: 1984-1990. https://doi.org/10.1016/j.bmcl.2007.01.017

102. McCready J, Sims JD, Chan D, Jay DG (2010) Secretion of extracellular hsp90alpha via exosomes increases cancer cell motility: a role for plasminogen activation. BMC Cancer 10:294. https://doi.org/10.1186/14712407-10-294

103. Baker-Williams AJ, Hashmi F, Budzynski MA, Woodford MR, Gleicher S, Himanen SV, Makedon AM, Friedman D, Cortes S, Namek S, StetlerStevenson WG, Bratslavsky G, Bah A, Mollapour M, Sistonen L, Bourboulia D (2019) Co-chaperones TIMP2 and AHA1 competitively regulate extracellular HSP90:client MMP2 activity and matrix proteolysis. Cell Rep 28(1894-1906): e1896. https://doi.org/10.1016/j.celrep.2019.07.045

104. Kumar DK, Choi SH, Washicosky KJ, Eimer WA, Tucker S, Ghofrani J, Lefkowitz A, McColl G, Goldstein LE, Tanzi RE, Moir RD (2016) Amyloid-beta peptide protects against microbial infection in mouse and worm models of Alzheimer's disease. Science translational medicine 8:340ra372. https://doi. org/10.1126/scitranslmed.aaf1059

105. Lee HG, Casadesus G, Zhu X, Takeda A, Perry G, Smith MA (2004) Challenging the amyloid cascade hypothesis: senile plaques and amyloidbeta as protective adaptations to Alzheimer disease. Ann N Y Acad Sci 1019: 1-4. https://doi.org/10.1196/annals.1297.001

106. Dickey CA, Kamal A, Lundgren K, Klosak N, Bailey RM, Dunmore J, Ash P, Shoraka S, Zlatkovic J, Eckman CB, Patterson C, Dickson DW, Nahman NS Jr, Hutton M, Burrows F, Petrucelli L (2007) The high-affinity HSP90-CHIP complex recognizes and selectively degrades phosphorylated tau client proteins. J Clin Invest 117:648-658. https://doi.org/10.1172/JCI29715

107. Ambegaokar SS, Jackson GR (2011) Functional genomic screen and network analysis reveal novel modifiers of tauopathy dissociated from tau phosphorylation. Hum Mol Genet 20:4947-4977. https://doi.org/10.1093/ $\mathrm{hmg} / \mathrm{ddr} 432$

108. Liao L, Cheng D, Wang J, Duong DM, Losik TG, Gearing M, Rees HD, Lah JJ, Levey Al, Peng J (2004) Proteomic characterization of postmortem amyloid plaques isolated by laser capture microdissection. J Biol Chem 279:3706137068. doi:10.1074/jbc. M403672200

109. Wilhelmus MM, Boelens WC, Otte-Holler I, Kamps B, Kusters B, MaatSchieman ML, de Waal RM, Verbeek MM (2006) Small heat shock protein HspB8: its distribution in Alzheimer's disease brains and its inhibition of amyloid-beta protein aggregation and cerebrovascular amyloid-beta toxicity. Acta Neuropathol 111:139-149. https://doi.org/10.1007/s00401-0050030-z

110. Wilhelmus MM, de Waal RM, Verbeek MM (2007) Heat shock proteins and amateur chaperones in amyloid-Beta accumulation and clearance in Alzheimer's disease. Mol Neurobiol 35:203-216

111. Wilhelmus MM, Otte-Holler I, Wesseling P, de Waal RM, Boelens WC Verbeek MM (2006) Specific association of small heat shock proteins with the pathological hallmarks of Alzheimer's disease brains. Neuropathol Appl Neurobiol 32:119-130. https://doi.org/10.1111/j.1365-2990.2006.00689.x

112. Serrano-Pozo A, Frosch MP, Masliah E, Hyman BT (2011) Neuropathological alterations in Alzheimer disease. Cold Spring Harbor perspectives in medicine 1:a006189. https://doi.org/10.1101/cshperspect.a006189

\section{Publisher's Note}

Springer Nature remains neutral with regard to jurisdictional claims in published maps and institutional affiliations.

Ready to submit your research? Choose BMC and benefit from:
- fast, convenient online submission
- thorough peer review by experienced researchers in your field
- rapid publication on acceptance
- support for research data, including large and complex data types
- gold Open Access which fosters wider collaboration and increased citations
- maximum visibility for your research: over 100M website views per year
At BMC, research is always in progress.
Learn more biomedcentral.com/submissions

